\title{
Research Issue on Green Product Design and Manufacturing of Electronic Manufacturing Industry
}

\section{Monika Bhatnagar ( $\square$ monikabhatnagar78@rediffmail.com )}

Galgotias College of Engineering and Technology

\section{Richa Gupta}

Maharaja Surajmal Institute of Technology

\section{Meena Rao}

Maharaja Surajmal Institute of Technology

\section{Tripti Sharma}

Maharaja Surajmal Institute of Technology

\section{Ajay Singh Yadav}

SRM Institute of Science and Technology

\section{Bhaskaran R}

PSNA CET: PSNA College of Engineering and Technology

\section{Research Article}

Keywords: Green technology, Green process, sustainability, pollutant, eco-friendly, environmental standard, Environmental Conscious Manufacturing (ECM), eco-design

Posted Date: April 22nd, 2021

DOI: https://doi.org/10.21203/rs.3.rs-436257/v1

License: (c) (1) This work is licensed under a Creative Commons Attribution 4.0 International License.

Read Full License 


\title{
Research Issue on Green Product Design and Manufacturing of Electronic Manufacturing Industry.
}

\author{
${ }^{1}$ Dr.Monika Bhatnagar, ${ }^{2}$ Richa Gupta, ${ }^{3}$ Dr. Meena Rao, ${ }^{4}$ Tripti Sharma, ${ }^{5}$ Ajay Singh Yadav, \\ ${ }^{6}$ Bhaskaran R
}

${ }^{1}$ Associate Professor, Galgotias College of Engineering and Technology, Greater, Noida- 201310 monikabhatnagar78@rediffmail.com

${ }^{2}$ Assistant Professor, Electronics and Communication Department, Maharaja Surajmal Institute of Technology,C-4 Janakpuri, Delhi, richaguptamsit@gmail.com

${ }^{3}$ Associate Professor, Department of Electronics and Communication Engineering, Maharaja Surajmal Institute of Technology, C-4, Janakpuri, New Delhi, India 110058, meenarao@msit.in

${ }^{4}$ Associate Professor, Information Technology, Maharaja Surajmal Institute of Technology, C-4,Janakpuri, New Delhi, 110058, tripti_sharma@msit.in

${ }^{5}$ Assistant Professor, Department of Mathematics, Faculty of Engineering and Technology, SRM Institute of Science and Technology, NCR Campus, Modinagar, Uttar Pradesh-201204, India, ajay29011984@gmail.com

${ }^{6}$ Professor, Department of Information Technology, PSNA College of Engineering \& Technology, Dindigul -624622, rbhaskaran@psnacet.edu.in

\begin{abstract}
In the industrial society, the concept of green product research is becoming prevalent in many manufacturing industries. The green technology is implemented to develop an environmentally green product that brought attention to a growing technological field as it attains sustainable growth in a market. The green process includes logistics, manufacturing, and product design to reach a high level of sustainability. The utilization of green technologies in manufacturing industries reduces the major effect of industrial outcomes on environment. The product manufactured in the electronic industries is rapidly utilized by more population. This paper deals with the research issue faced during product manufacturing in electronic industries. Initially, the issues encountered during product development are air pollution, solid waste, and water pollution. The product is enriched with the characteristic features such as an increase in efficiency, reduction in toxic content, and must be eco-friendly. The developed green product should satisfy environmental standards. Environmental Conscious Manufacturing (ECM) accountability to satisfy the government rules and regulations for product development in the manufacturing industry and also deals with the customer's expectation. The eco-friendly product includes ecodesign, recycling, clean production, low cost, and reclamation of products. The eco-design is responsible for improving the environmental outcomes and also reliable for a reduction in long-
\end{abstract}


term cost. The green product design and manufacturing focus mainly on energy conservation and the development of a product with less wastage. The research on green product manufacturing is mainly to save the environment by reducing carbon foot print and to make the product in less cost. The main consequence faced during the development of the green product is destroying the environment by utilizing natural resources. Thus, in this paper, the issues faced during the green product design and manufacturing of the electronic manufacturing industry are discussed.

\section{Keywords}

Green technology, Green process, sustainability, pollutant, eco-friendly, environmental standard, Environmental Conscious Manufacturing (ECM), eco-design.

\section{INTRODUCTION}

Nowadays, electronic waste disposal is a major issue faced in the world. Green technology is the application which deals with environmental conditions, monitoring the ecosystem, green chemistry, electronic devices are assigned for monitoring the ecosystem continues to provide the report regarding the changes occurring in the environment by the Electronic Manufacturing Industries. Implementation of Green technology is responsible for protecting natural resources and also reduces the negative impact on the environment. The term 'Green technology' describes a constant supply of energy effectively to withstand the product in the market for a high-profit range.

In many developing countries, Electronic Manufacturing Industries are encountered for their increased import and export of products in the manufacturing sector. The manufacturing sector recognized for its output growth and improvement in product index. The main issues arising from Electronic Industries are improper waste disposal management which is highly hazardous to the environment as well as to all living Organisms and generation of pollution from the industrial sector [1].

The green technologies and processes concept is adapted for many years for product development in manufacturing industries. Green technology and processes are used for multi-application purposes. In industries, the processes are preferred in the production field as it does not affect the environment. The green process includes the development of the product followed by the lifecycle management. The reusability, recycling, clean production, and eco-design are focused on product enhancement and hence, the production, distribution, utilization, and removal of product wastage are carried out effectively [2]. The main purpose for the development of green technology to provide a healthy environmental condition where the natural energy sources are used as a raw material for the product design [3]. The green resources and the green technological product brings unique attention to the consumer side and hence, it comes under the responsibility of the society [4]. A society action and involvement are more important in opposing the unhealthy product and supporting the healthy product in the market. The healthy green product manufactured should undergo the recycling process to avoid damage to the eco-system [5]. 
Depending on the human necessities, the product has been designing and implemented in a business orientation to earn profit in the market still the product is not environmentally sustainable [6]. The Industrial sector has to satisfy sustainable environmental, social, and economic concerns [7]. The industries concentration to earn profit and to satisfy the human expectation on the other hand they lack in wealth distribution, leading to the environmental depletion, over-cultivation of ecological services. This preference for human needs concerning the ignorance of environmental status leads to unsustainability [8]. The challenging issue identified are classified into four different types. They are system and success level, strategy level, action level, and tools level. In the system and success level, human activity takes the majority of the societal action within the ecosystem. The product being developed has to be sustainable for the long-term of life which is highly dependent on nature. Extraction of natural resources from the earth crust, more societal waste substances, exploiting both the life of living organisms and environment and not compulsorily needed to meet the society people needs are the system conditions [9].

The proper investment in enhancing the product and the designing and manufacturing of the product should be under the term and conditions of the system. The economically sound investment is required for the continuous process. The system and success level includes the action being executed from the product design. The action level is responsible for increasing the profit based on business activities simultaneously reduces environmental impacts. The tool level is engaged to continuously monitor the activities of the activity level and this level starts its work in the action level under the guidance of the action level. The tool level and action level both gather and exchange information among themselves is more effective in identifying the problems that arise not for a sustained society. The challenges identified during the eco-design are the deficiency of a tool to achieve the system and success level. Depending on the selection of tools, the sustainable impact on the environment is reduced [10].

The performance of the eco-design is fully influenced by the end-users. End-user decides the lifetime for the product where the system and success level conditions are affected [11]. If the product is developed either based on the environmental aspects or end-user's requirements. The product system depends on the employee for manufacturing purposes and the employee is needed for the whole supply chain [12]. The main aspects to be considered for designing and manufacturing a product are the environmental aspects, economical aspects and social aspects that is more challenging to attain [10].

There are various methods and approaching ideas for the Design for Environment (DfE) and Sustainable Product Development (SPD). Satisfying both the consumer and the ecosystem terms and conditions are more difficult for a product developer [13]. The sustainable eco-design tool is not uniform; it will differ as per the scope of use. The policy has to be framed for the development of the whole life chain of the product but still, it is challenging in practical life to create effective legislation [12]. The hazardous product or the materials used in creating a product should be avoided but still, these materials are not avoided in the manufacturing industries. This problem even has to be considered in Electronic Manufacturing Industries [10]. 
The challenges in the strategic level are the initial eco-design performance even struggles with some barriers, these barriers are difficult to handle [14]. Human employees, knowledge about the barrier, and environmental impact are the biggest issue encountered, and hence, these to be handled carefully [15]. The eco-design model has to be implemented can solve the consequence that arises in the manufacturing industries [16]. Lack of expert person in supporting the implementation and processing of eco-design and tool handling. The requirement of manpower and time for the management and implementation of eco-design is difficult [14]. From a system and success level perspective, the eco-design is limited practically where the development and management are not included under the implementation of eco-design [17].

The product specification is environmentally oriented and product development involves the formal with some specifications is difficult in implementing along with the whole life cycle and chain value of a product. This is challenging in case of evaluation and solving the consequence [12]. The tool includes the material where suitable material determining is a bit difficult for a designer on a functional basis [18]. The research has to be carried for a proper selection of material from the tool level for sustainable product management. The focus on the tool level is more important as this causes the barrier depending on the strategy level ([12] and [15]). The issues recorded related to the material, product, materials involved in product manufacturing, the process involved in design and manufacturing, and other stages of the product life cycle [14].

Electronic Manufacturing Industries mainly deals with the improvement in energy and resource efficiency. There are more techniques available for improving energy efficiency which are undesirable impacts on the production sector [19]. The energy efficiency is increased concerning certain constraints. The constraints deal with the production, technology, and resources for enhancing efficiency [20]. Green Manufacturing practices are considered to reduce environmental impacts during product development. The research provides detailed information regarding the role of manufacturing industries, the usage of materials in the manufacturing sector, the product meets the environmental standard conditions, also discussed the issues that arise during the green product design and manufacturing in the Electronic Manufacturing Industries [21].

\section{LITERATURE SURVEY}

According to the World Conservation Strategy report, the term "Sustainable Developed" was

familiarized by the International Union for Conservation of Nature and Natural Resources. The report was completely dealing with the development regularly on the planet in the technological field without any disturbance to living organisms and damage to the eco-system ([21] and [22]). The sustainable development was perfectly viewed in the Brundtland report, certified by the United Nations (UN). The exploitation of natural resources to satisfy the present need of human beings where they ignoring the future generation's life at risk without a healthy environment and natural resources. This paper gave a complete report from the absorption of human activities meeting their needs with irrespective damage to the environment. There was no limitation for such activity but still, the limit for the exploitation of natural resources should be notified [23]. 
The innovation regarding the green product increased the demand on business and customer's side, and also recognized for its reduced impact on the environmental side [24]. The procedure carried by the Europe INNOVA was responsible for providing a health management system with less toxic in association with low economically priced products as per the human need and also minimized the effect on the environment [26]. From the industrial point of view, the green product brought unique attention in the market as the product developed was eco-friendly and even preferable by many consumers would lead to an increment in the profit [27]. In the competitive world, the manufacturers mostly wanted to sustain their product constantly in the market and their brand, and hence, the manufacturer ignores the green product with less toxic content. The environmental impact issue was highly linked with the economical process for the development of eco-innovation was stated by the Organization for Economic Co-operation and Development (OECD). The ecoinnovation includes the production process, marketing the product, establishment of the organization, institutional attention with the corresponding improvement in the environment and it was more important for both the business person and policymakers. Like other types of innovative technologies, the impact of the eco-innovation was comparatively very low. Only depending on the economic status and the impacts regarding the environment, the eco-innovation in the society would be encouraged further [28]. The innovation of any new green product included the objectives such as limited usage of natural resources, reduced pollution, the cost for the disposal of waste products, and its management.

The development of a new green product with a modified process, practices, system, and product would lead to a sustainable environment [29]. The green innovation was also considered as the hardware or software innovation as it performed the green process which is recognized for energysaving, prevention from pollution, recycling of the electronic waste product, green product design along with environmental management. The innovation object included the product, process, service, and method. The market orientation was assigned to meet the level in the competitive business. The negative impact reduction comes under environmental aspects. Impulse reduction in an ecological way and as the responsibility to set the product to a new standard to the firm ([25] and [26]). The analyzation of input and output factors ultimately to reduce the consumption of natural resources. The intention for the reduction of ecological impulse was to reduce the material used for the development of a new product with less impact and toxic content.

A systematic literature review was about the green product design and manufacturing using the green process in Electronic Manufacturing Industries. This paper gave information regarding sustainability through the analysis of various researches on the green product [31]. Sustainability in various aspects was discussed in the industrial world to provide information regarding the digital revolution [32].

The comprehensive overview on the green business process management and its application was explained [33]. A systematic study of green business process management concerning its capabilities, techniques, and environmental risk [34]. However, the green product design in the developed industrial field, sustainability in manufacturing were difficult to achieve together. In 
this literature review, the green process issues were focusing on the processes carried by various technologies, fields, and areas. The review paper mainly deals with the electronic waste management and recycling [35], various green processing techniques [36], supercritical fluid carbon dioxide process [37], electrical discharge machining [38], green supply chain process [39], logistic process [40], and green chemical process and synthesis [41]. Green chemistry was more preferable among different techniques of the green process. Waste disposal, Safer syntheses, auxiliaries, renewable feedstock, catalysis, preventing pollution and accidents, atom economy, development of the eco-friendly product, energy efficiency, reduction in derivatives, and degradability [42]. Operating, commercial and economic benefits were the features required for the sustainable output of green processes [43].

The review made on the green and low carbon technology innovation between 1994 and 2010 [44]. The literature review provided information regarding the issues that occurred during the green product design in manufacturing industries in consideration of the social field and sustainability [45]. Some of the Green technology discussed during the review were green fertilizer technology adoption [46], harvesting green energy [47], natural fiber in the automotive industry [48], green biodiesel [49], oil extraction using subcritical water technology, and biodiesel production [50], iron and steel manufacturing used energy-efficient co2 technology [51], metal additive manufacturing process [52], oilfield scale handling is possible through scale inhibitors [53]. The review of different technologies in manufacturing green products in the developing industrial sectors includes economics, management, and industrial construction.

\section{SYSTEM MODEL:}

Green technologies implementing in Electronic Manufacturing Industries reduces the effect of causes due to product manufacturing. Electronic devices are utilized to monitor the actions in the manufacturing industries. The green process is recognized for producing a sustainable product in the market. The green product brought the attention of more people as the product is environment friendly.

The material used in the manufacturing industries in the product development and the respective output is under the control of Environmental Management Tools. Management Tool determines product efficiency and also responsible for disposing of the waste outcome from the industries. The total product cost is based on the material used for designing and manufacturing the product, employee involvement in the work, waste disposal, and sundry item cost. The cost estimation has to be obtained from the systematic engineer format. The manufacturer takes the responsibility of achieving the critical leverage point that should satisfy both the environmental conditions as well as the business aspects. Recycling the product will reduce the impact on the environment and hence, it's the responsibility of the manufacturer to develop the product initially as a reusable product with the usage of less toxic materials. Depending on the selection of the materials, the estimation of the product life span is achievable. 
The contamination and depletion of natural resources is the main reason for the development of a sustainable product. The reduction of environmental impact is acquired only through sustainable manufacturing. The development of sustainability in the atmosphere of an eco-system is shown in Figure1.

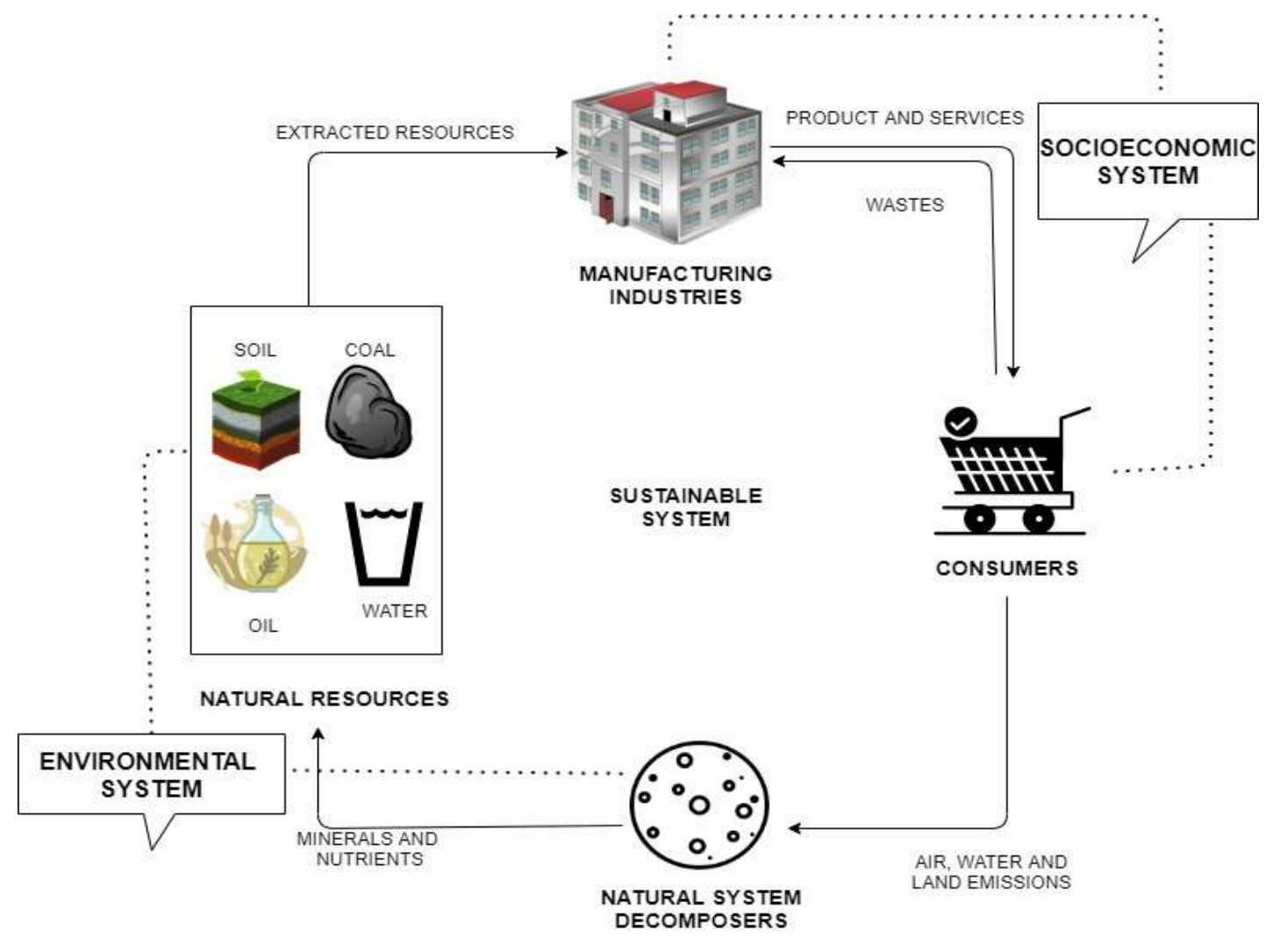

Figure 1: Green Product Manufacturing for a Sustainable Development.

\section{Green Supply Chain Management in Electronic Manufacturing Industries:}

Innovative management of eco-system utilizes the green operation (GO) in Electronic Manufacturing Industries to handle electronic components and metals and ensure a healthy environment. Green operation is the most suitable innovation carried out in industries to balance both the economic status as well as the pollution in the environment. The task such as product design, processing, packing, and marketing are held with the support of non-renewable materials and hence, it is hazardous free. Electronic manufacturers determine the impact of a product on the eco-system still the end-of-life. 


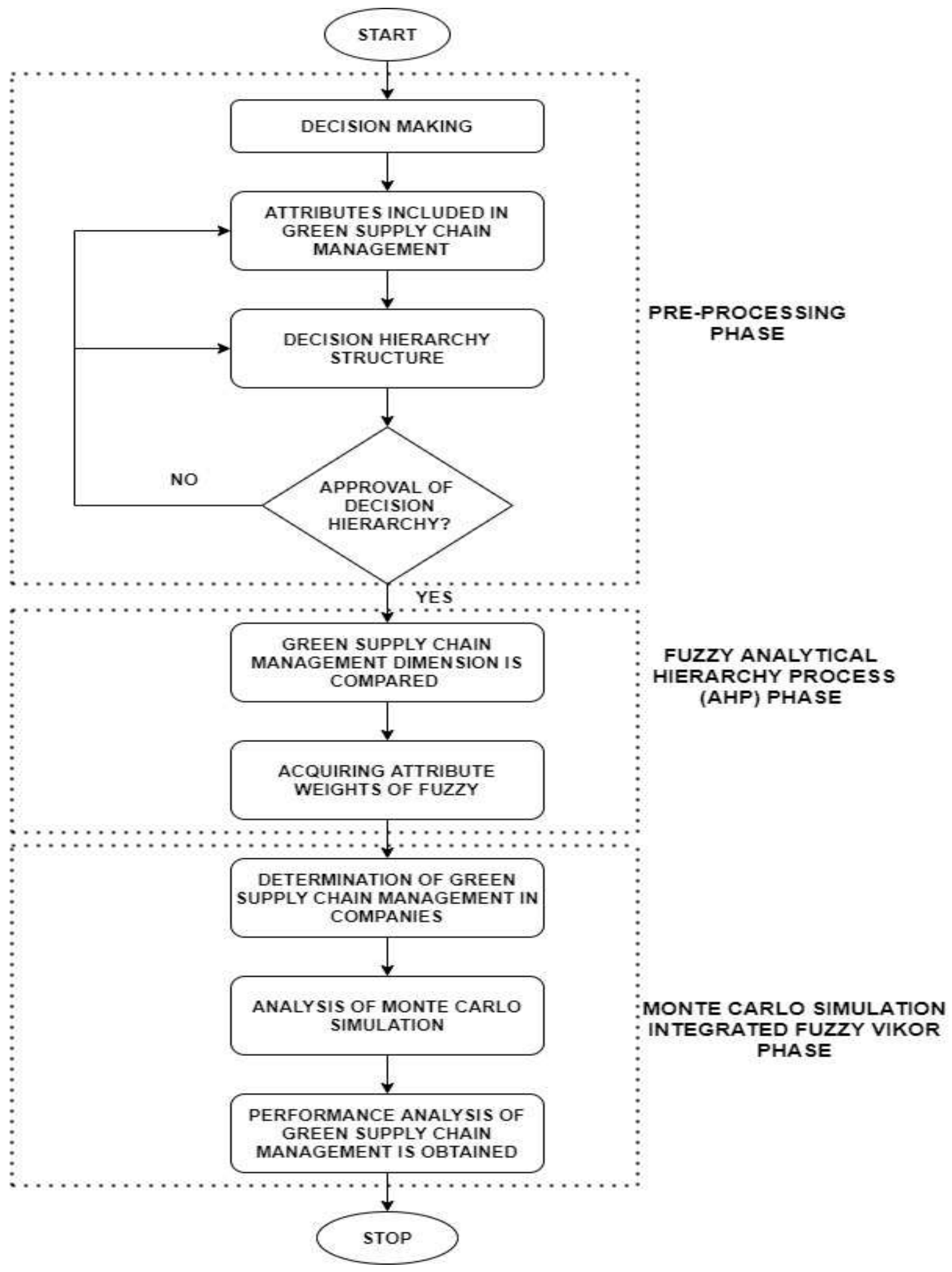

Figure 2: Green Supply Chain Management. 
GSCM consist of product design, material sourcing, selection and the manufacturing process. The performance efficiency of an Electronic Manufacturing Industries is obtained using Green Supply Chain Management in green product design and manufacturing is shown in Figure 2.

Step1: Decision maker select the linguistic term to proceed with the pairwise comparison depending on each attribute of Green Supply Chain Management (GSCM). The theoretical matrices are constructed to compare the fuzzy pairs.

$$
A^{-k}=\left[\begin{array}{cccc}
1 & a^{-k}{ }_{12} & \ldots \ldots & a^{-k}{ }_{1 n} \\
a^{-k}{ }_{21} & 1 & \ldots \ldots & a^{-k}{ }_{2 n} \\
\vdots & \vdots & \vdots & \vdots \\
a^{-k}{ }_{n 1} & a^{-k}{ }_{n 1} & \ldots \ldots & 1
\end{array}\right]
$$

Where $\mathrm{k}=1,2, \ldots \ldots, \mathrm{k}$.

Step2: During the computation of synthetic pairwise comparison matrix, geometric mean technique is utilized.

$$
\overline{a_{i j}}=\left(a^{-1}{ }_{l j} \otimes a^{-2} i j \otimes \ldots \otimes a^{-k}{ }^{i j}\right)^{1 / k}
$$

Step3: Computing thefuzzy weight of each attribute using geometric mean method. The geometric mean value of fuzzy is expressed as follows,

$$
\overline{s i}=\left(\overline{a_{11}} \otimes \cdots \overline{a_{i j}} \otimes \ldots . \overline{a_{i n}}\right)^{1 / n}
$$

The fuzzy weight of the $\mathrm{i}^{\mathrm{th}}$ attribute value is expressed as follows,

$$
\left.\overline{x_{i}}=\bar{s}_{i} \otimes \bar{s}_{i} \oplus \ldots \oplus \bar{s}_{i} \oplus \ldots \oplus \bar{s}_{s_{n}}\right)^{-1}
$$

Step4: Analytical Hierarchy Process (AHP) is used to determine the fuzzy weight depending on the selected attributes. 


$$
\bar{D}=A_{1}\left[\begin{array}{cccc}
C_{1} & C_{2} & \ldots & C_{n} \\
\bar{y}_{11} & \bar{y}_{12} & \ldots & \bar{y}_{1 n} \\
\bar{y}_{21} & \bar{y}_{11} & \ldots & \bar{a}^{-k}{ }_{2 n} \\
\vdots & \vdots & \vdots & \vdots \\
\bar{y}_{m 1} & \bar{y}_{m 2} & \ldots . & \bar{y}_{m n}
\end{array}\right]
$$

Where $i=1,2, \ldots ., m ; j=1,2, \ldots \ldots, n$

$$
\overline{y_{i j}}=(1 / k)\left(\bar{y}^{1}{ }_{i j} \oplus \bar{y}_{i j} \oplus \ldots \oplus \bar{y}_{i j}\right)
$$

Step5: Constructing the performance rating matrix using the Monte Carlo simulation. In this step, the attribute based fuzzy weight is converted to a triangular probability distribution to determine the performance efficiency of Green Supply Chain Management (GSCM).

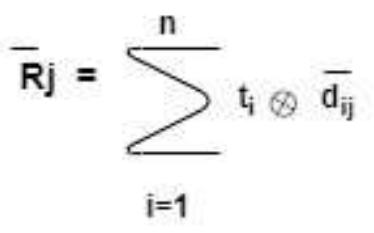

The identification of issues in the green product in association with the supply chain management is familiarly known to be Green Supply Chain Management (GSCM). GSCM represents the supply chain among the manufacturers, reversal logistics, and customers from the supplier, and this representation is known as a closed-loop supply chain. Environmental management is linked with green product design and practical implementation, after the end-of-life, it can be recycled and used again with less impact on the eco-system. Green Supply Chain Management is preferred in the automobile industry as it increases the global economy rapidly. The greening chain policy is adapted internationally as it has more benefits to an eco-system as well as the organization. Identifying and recording the green design impact helps us to evaluate the performance of the green product design and its manufacturing. The main reason to apply the green process concept in automobile industries is to reduce the impact and to reach the product high level in the market. Still, the recycling product also lacks the attention of customers due to the environmental burden. To overcomes the consequences, Green Supply Chain Management is adapted in all industries.

Renewable energy sources such as solar, tidal, wind, biodiesel, etc., are some of the green products. These renewable energy sources as the ability to produce sustainable energy. Water is the essential one for living organisms and fuel is more important in human's day-to-day life. The fuel can be 
obtained through sustainable energy sources whereas the water is purified through a solar distillation process.

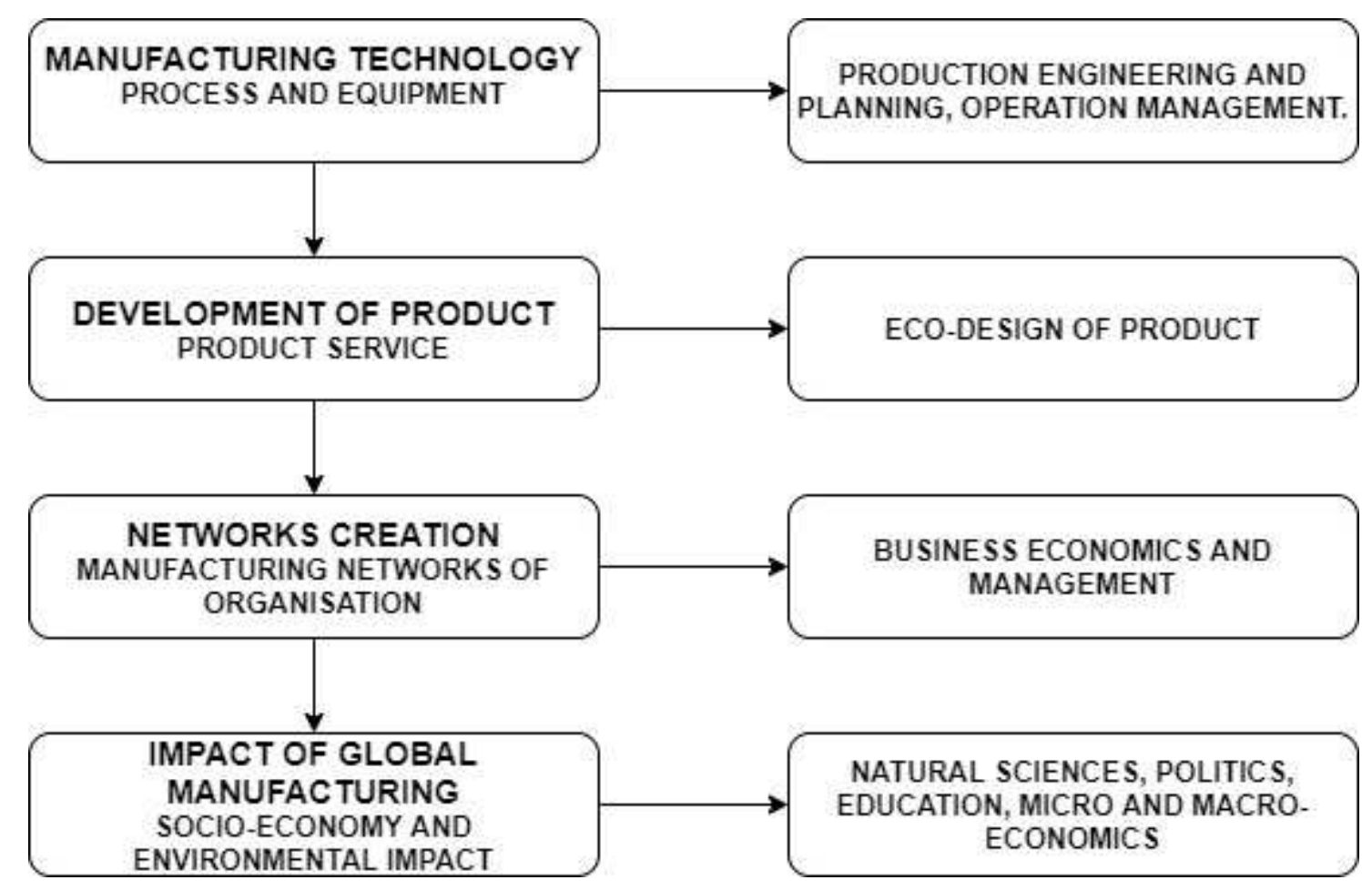

Figure 3: Flowchart for Sustainable Manufacturing.

From figure 2, sustainable manufacturing can be attained with the following procedures.

Manufacturing Technology: This step is more important where the suitable technique has to be adapted for sustainable growth and this step paves the way for network creation process and equipment. The main purpose for the selection of technology is to focus the improvement on the production site with a recognized machine-tool concept and ensure the management of the product being produced.

The manufacturing has an inbuilt indicator that has to continuously monitor the process carried out in the manufacturing industries. The energy consumption is maintained with the support of indicators depending on the measurement of machine tools. Cyber-physical systems and metering techniques are also employed to facilitate the processes within a manufacturing system. The machine tools provide the materials for the proper manufacturing of products. The selection of suitable manufacturing technology will reduce carbon dioxide emissions from the industries. This is familiarly known to be a Sustainability-driven Development of Manufacturing Technologies.

Development of Product: The operation management of manufacturing technology is resulting in product development. It subjects the systematic product which can achieve sustainability in all aspects. This process includes the integration of criteria mentioned for sustainable development. Environmental impact, business aspect, and marketing are satisfied. Reduction in environmental 
impact depends on product lifespan. The manufacturer has to design the product more efficiently. The product lifecycle management is integrated with the system information is analyzed for product development. In this stage, the manufacturer is provided with the freedom to design the product depending on the customer's expectations. The manufacturer is responsible for balancing both the business economy and environmental impact.

Networks Creation: The factors considered for creating an organizational product is known to be network creations. This is essential in developing the product as it provides the design, proper selection of materials, researching the issues in different aspects, and maintain the economic status. The manufacturer has to design the product with the recycling ability, testing of a product, and analyzing. The network creation is more important for a globalized supply chain process all over the world. The infrastructure of the organization is also more important as it enables safe product manufacturing and facilitates sustainable products. The individual should be highly benefited due to the coordination of the organization in product development.

Impact of Global Manufacturing: Sustainable product development includes the manufacturing activities and product performance. Global manufacturing is found to be the central part of green product design and manufacturing. Life Cycle Assessment gives complete information regarding the global impact due to product manufacturing. Global product manufacturing is more challenging to manufacture in practical. The research issue gives detailed information regarding the sustainability evaluation of green product design. Green technology and processes are used for multi-application purposes. In industries, the processes are preferred in the production field as it does not affect the environment. Product manufacturing is to be performed after the sustainability analysis and processing concerning the target mentioned by the Environmental Standard.

\section{RESULT AND DISCUSSION:}

Electronic Manufacturing Industries faces more difficulty in developing a sustainable value in this competitive world. The challenges and issues are encountered in business management. The features which are essential in manufacturing a green product are compared and analyzed as per the investigation. The factors response and its impact on the environment are analyzed in Table 1. Depending on the product quality and the impression over the company, future trends keep changing. In the growing technological life, the environmentally sustainable product is difficult to manufacture which is directing to more hazardous impacts. The factors which are considered for the constant development of industries are shown in Table1. This shows the relationship between the industries and the environment to maintain sustainability. Sustainable Development Goals (SDGs) are framed to link the organization with environmental sustainability. The factor which has both positive and negative impact on the environment is explained in a detailed manner. With the research made the manufacturer can select the materials eco-friendly with less impact. The materials are selected depending on the demand for the product due to the global economic growth.

Green logistic management is adapted by many exporters to earn more profit with respect to conservation of natural resources and to establish a profitable environmental performance. The GLM is includes the component such as evaluation of operational performance, identification of 
operational antecedents, and examination of environmental regulatory pressure. Green logistic is a part of the Green Supply Chain Management enrolled to minimize the ecological impact of logistics activities. GLM has a positive impact on environment and operational performance is obtained from figure 4 to figure 11.

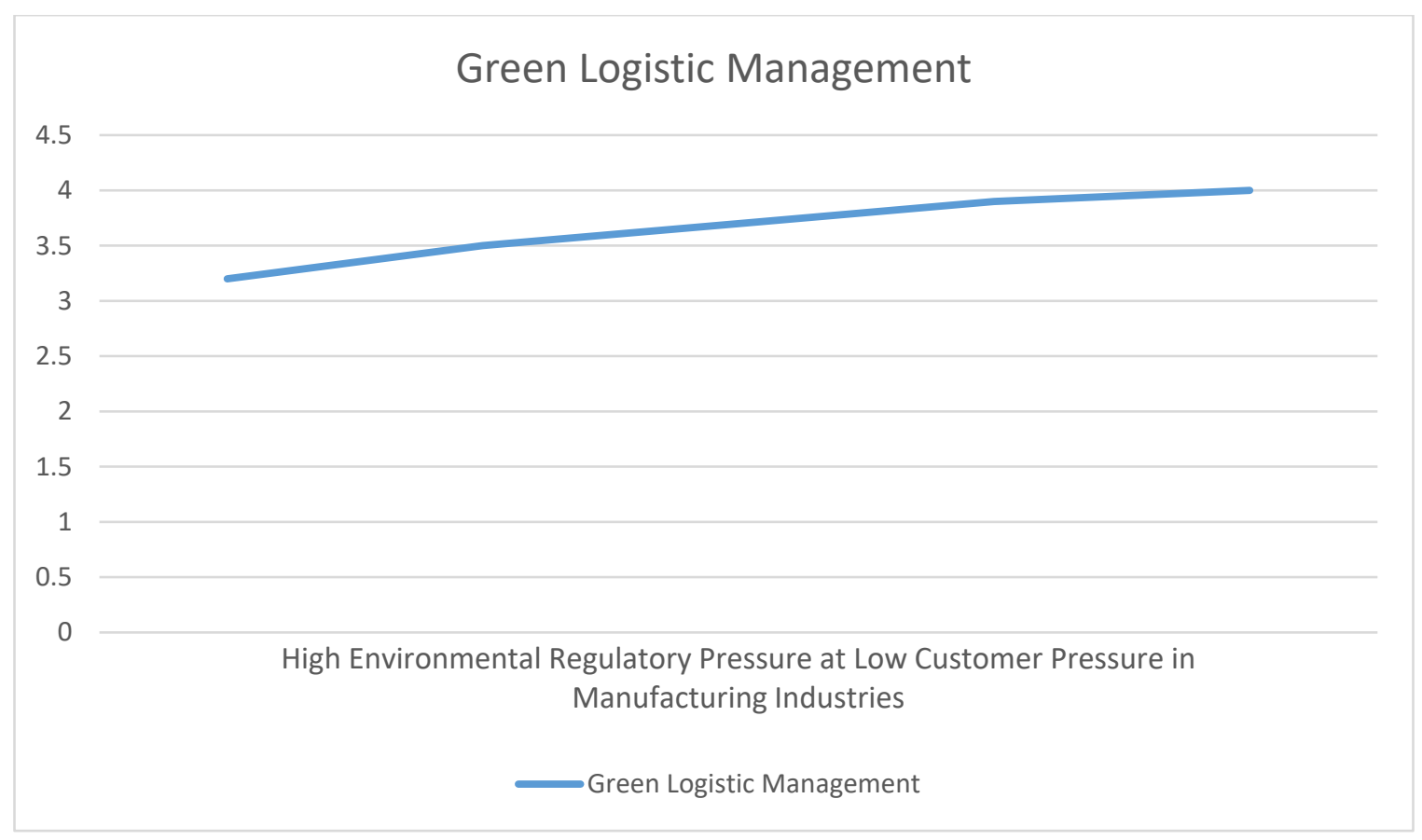

Figure 4:Green Logistic Management at Low Customer Pressure.

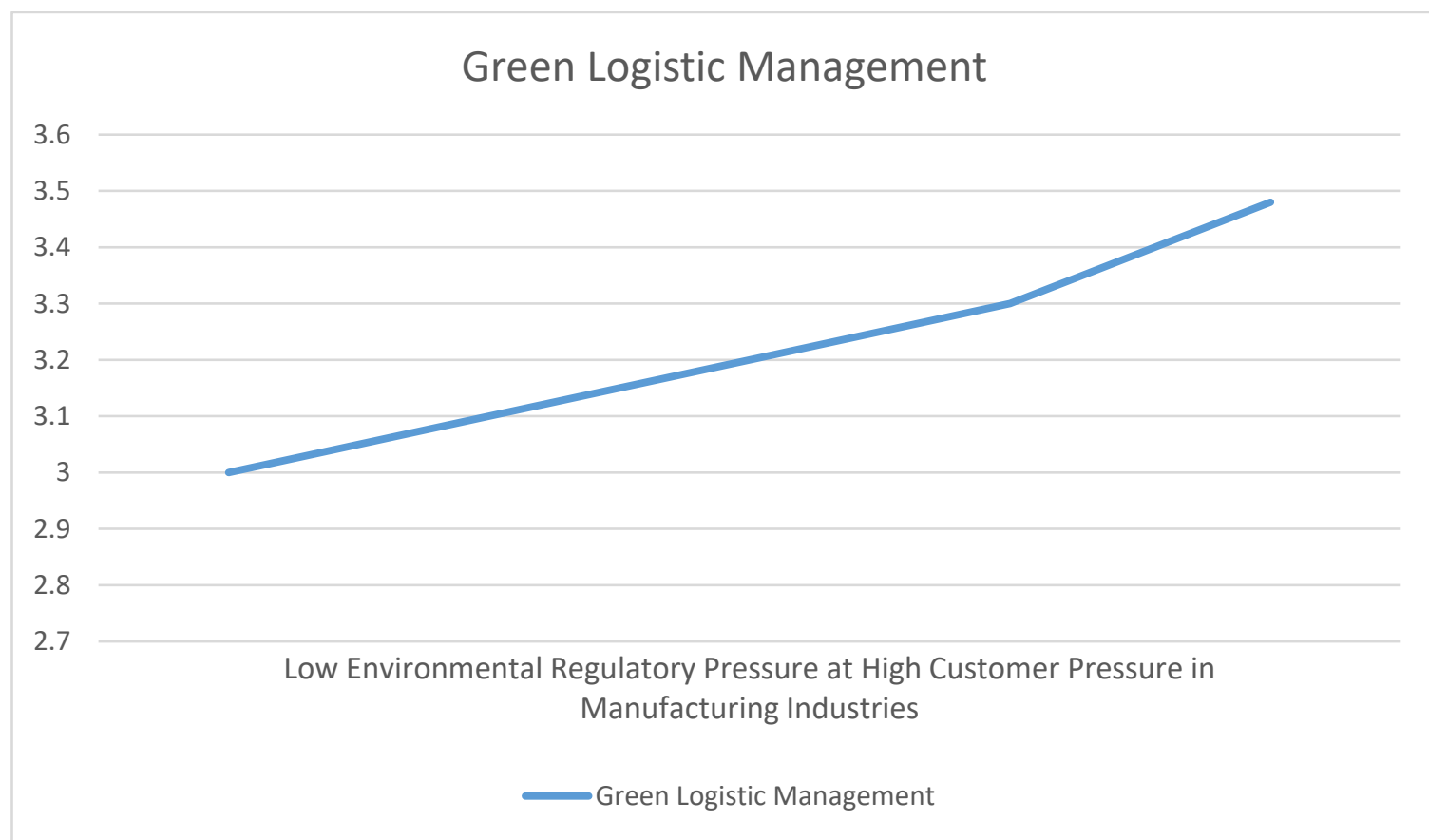


Figure 5:Green Logistic Management at High Customer Pressure.

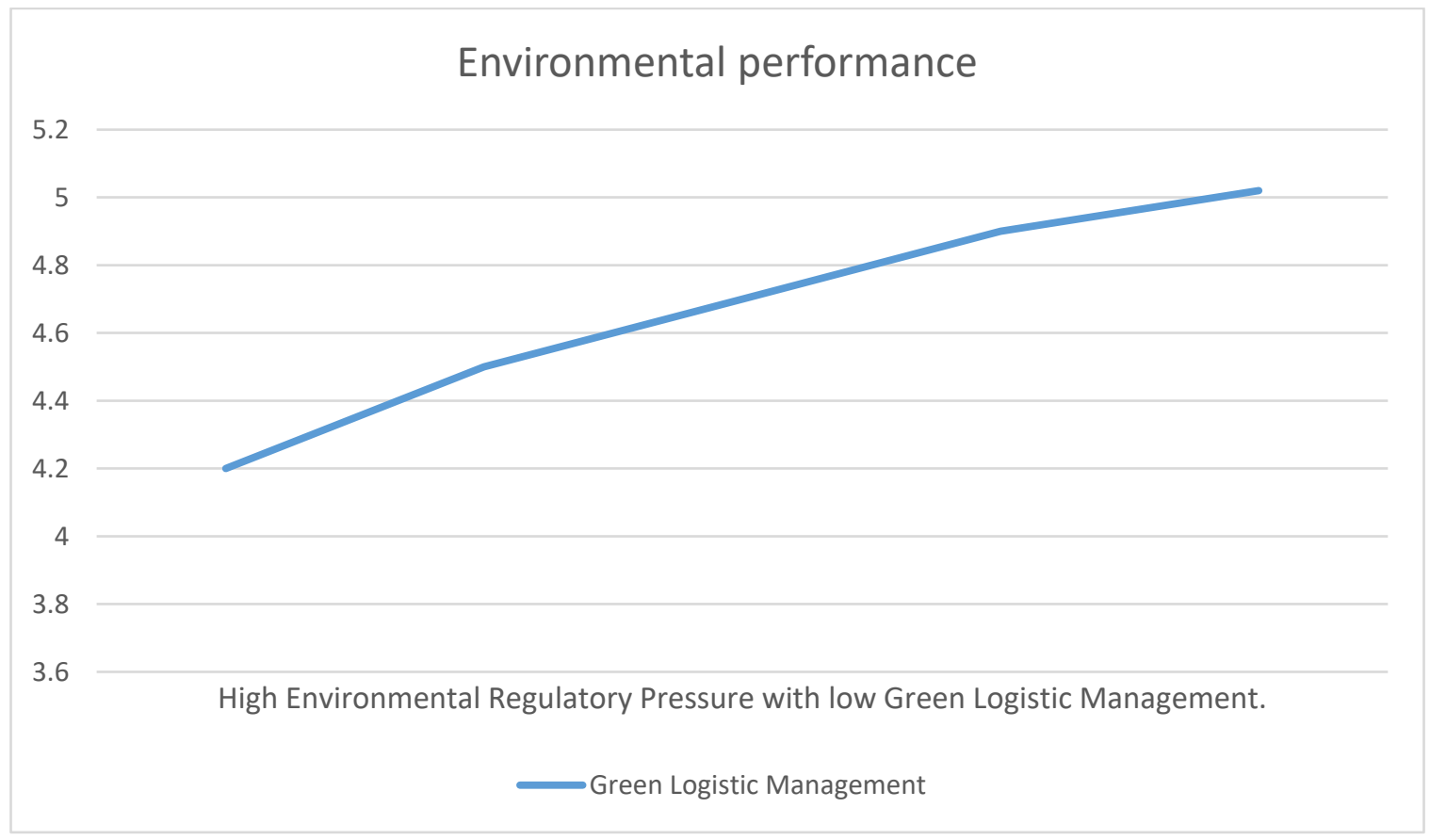

Figure 6:Environmental performance of Green Logistic Management.

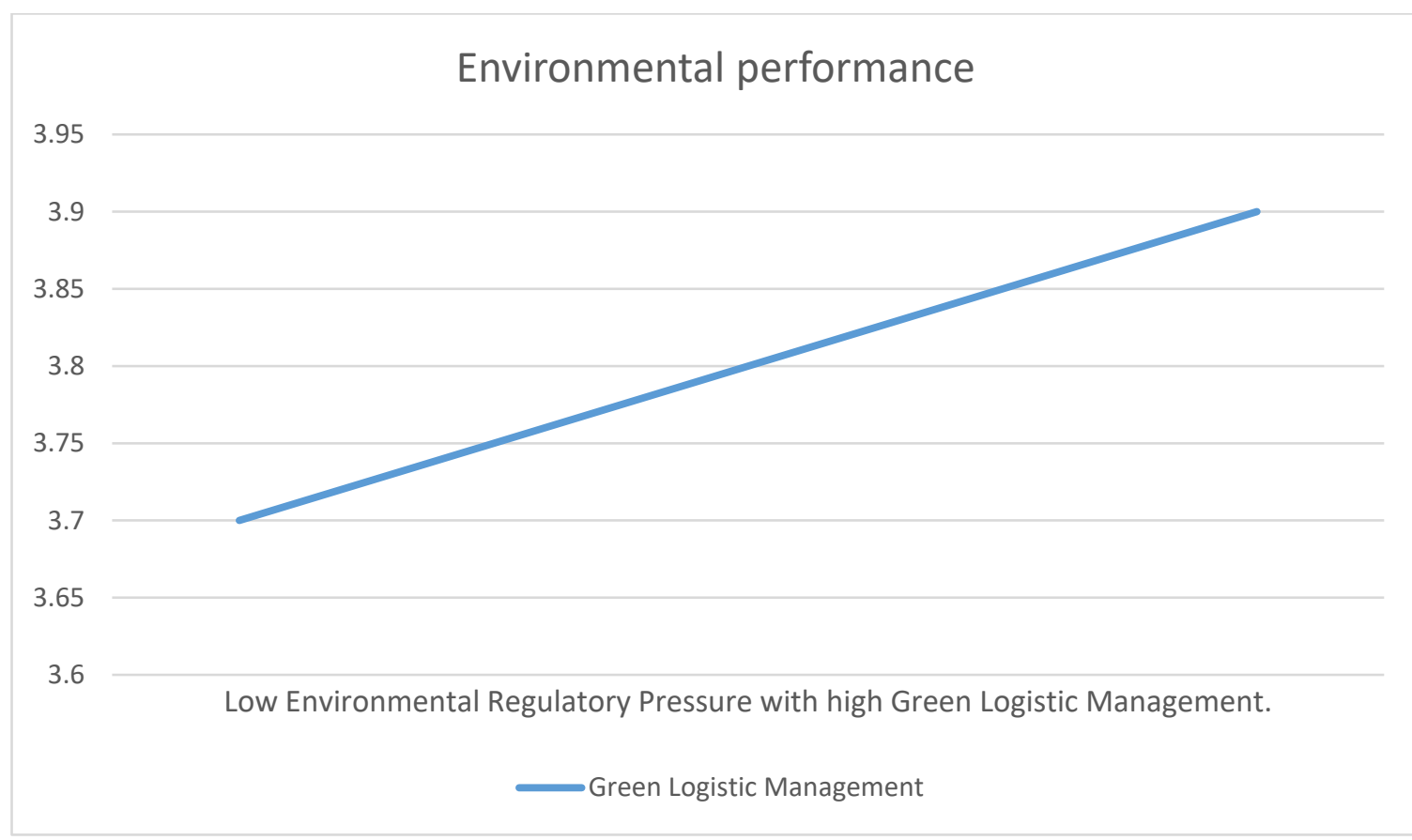

Figure 7:Environmental performance of Green Logistic Management. 


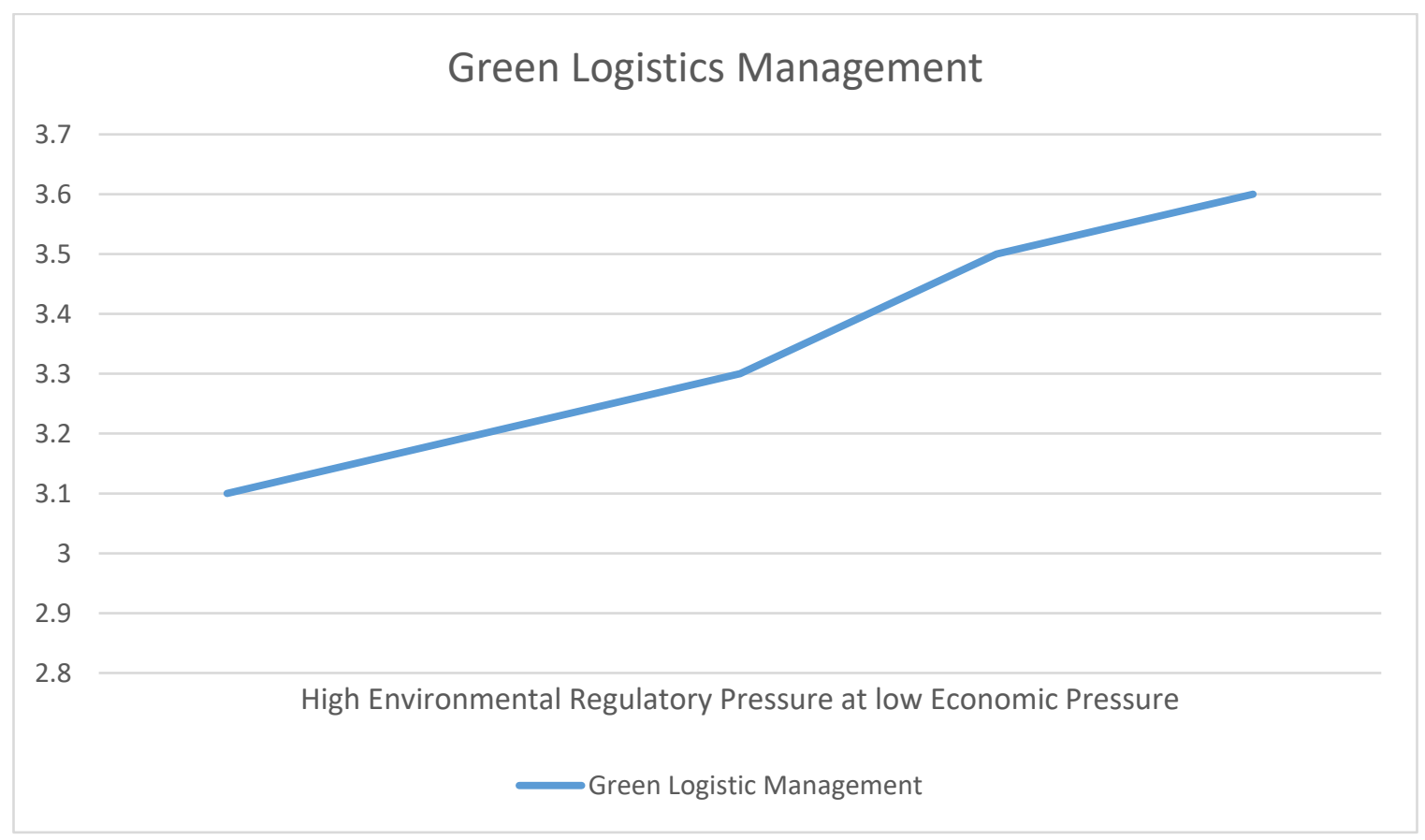

Figure 8: Green Logistic Management at Low Economic Pressure.

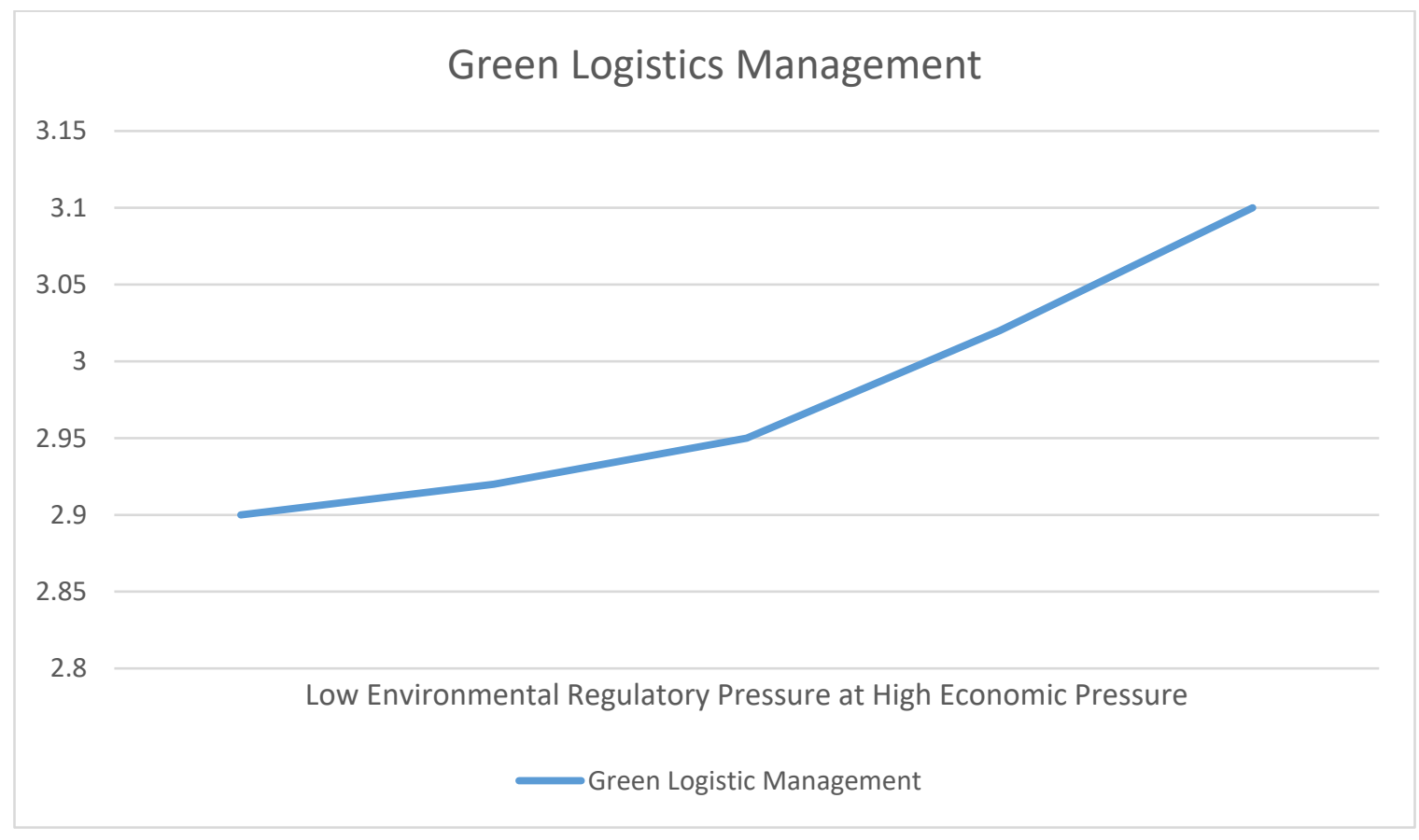

Figure 9:Green Logistic Management at High Economic Pressure. 


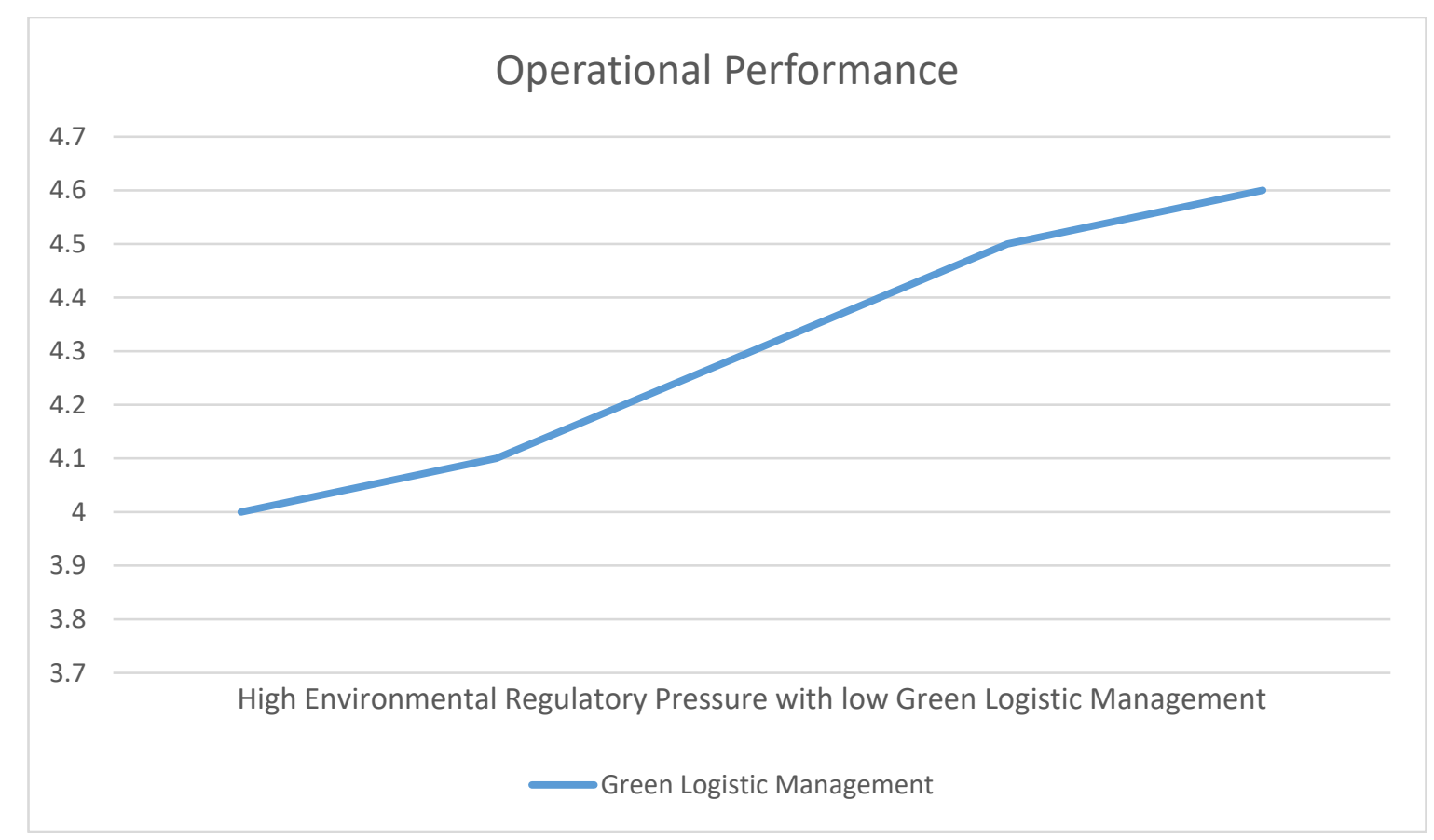

Figure 10:Operational performance of Green logistic management.

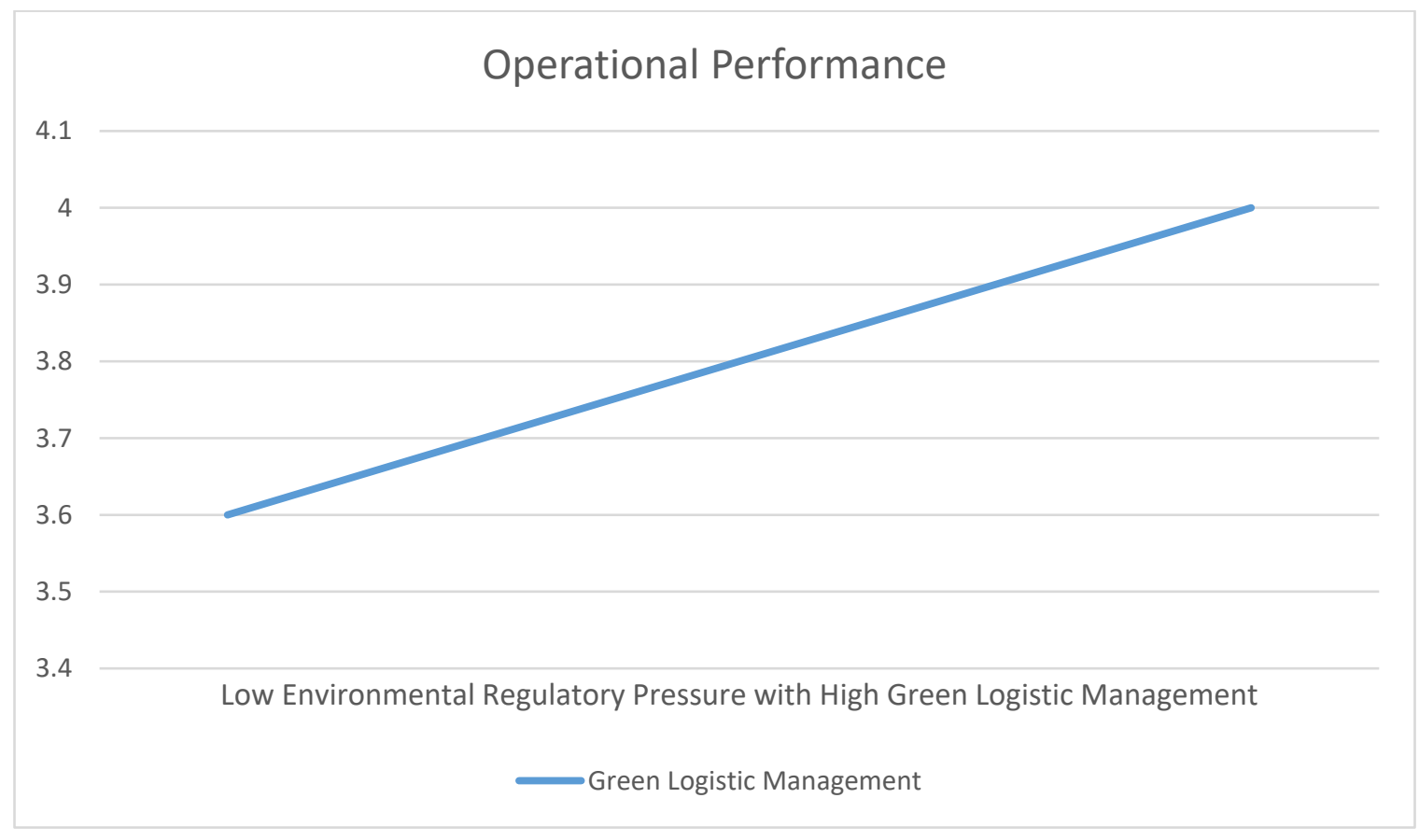

Figure 11: Operational performance of Green logistic management. 


\begin{tabular}{|c|c|c|}
\hline FACTORS & FEEDBACK & IMPACT \\
\hline \multirow[t]{2}{*}{ DEVICE } & $\begin{array}{l}\text { IMPROVEMENT IN } \\
\text { RECYCLING } \\
\end{array}$ & POSITIVE \\
\hline & $\begin{array}{c}\text { INCREASED } \\
\text { FABRICATED ELEMENTS }\end{array}$ & NEGATIVE \\
\hline RAW MATERIAL & $\begin{array}{c}\text { SUPPORT BOTH } \\
\text { RESEARCH AND } \\
\text { RECYCLING PROCESS. }\end{array}$ & POSITIVE \\
\hline \multirow[t]{2}{*}{ CONSUMER } & AWARENESS & POSITIVE \\
\hline & UNAWARE & NEGATIVE \\
\hline EMPLOYEE & $\begin{array}{l}\text { TRAINING AND WORK } \\
\text { MANAGEMENT }\end{array}$ & POSTIVE \\
\hline \multirow[t]{2}{*}{ COMPANY FRAMEWORK } & $\begin{array}{l}\text { DIGITIZATION AND } \\
\text { AUTOMATION } \\
\text { ANALOGOUSNESS }\end{array}$ & POSITIVE \\
\hline & $\begin{array}{l}\text { DIGITIZATION AND } \\
\text { AUTOMATION } \\
\text { ASSORTMENT }\end{array}$ & NEGATIVE \\
\hline BUSINESS ASPECTS & $\begin{array}{c}\text { ENVIRONMENTAL } \\
\text { SUSTAINABILITY WITH } \\
\text { SOCIO-ECONOMICAL } \\
\text { PROFIT }\end{array}$ & POSITIVE \\
\hline \multirow[t]{2}{*}{ GEOGRAPHY } & $\begin{array}{l}\text { SPATIAL ANALOGOUS } \\
\text { TECHNOLOGY }\end{array}$ & POSITIVE \\
\hline & $\begin{array}{c}\text { TECHNOLOGY } \\
\text { ADOPTION ONLY IN } \\
\text { DEVELOPED COUNTRIES }\end{array}$ & NEGATIVE \\
\hline \multirow[t]{2}{*}{$\begin{array}{l}\text { UNDESIRABLE } \\
\text { EQUIPMENT }\end{array}$} & $\begin{array}{l}\text { WASTE PRODUCT } \\
\text { DISPOSED AND } \\
\text { RECYCLED. }\end{array}$ & NEGATIVE \\
\hline & $\begin{array}{c}\text { REQUIREMENT OF } \\
\text { TRANSPORTATION FUEL }\end{array}$ & \\
\hline
\end{tabular}

Table 1: Analysis of factors examined for a sustainable development.

The research issue on green product design and manufacturing is analyzed depending on the technologies adapted on a direct link with environmental sustainability. The requirement for the product manufacturing and choice of material selection, eco-designing, manufacturing, and packing in different manufacturing industries as per the considerations. The trend which shows 
negative is in the exploiting stage which means it hurts the environment. The framing of policies and support innovation is required to achieve sustainable development goals. Some industries are using digitalized infrastructure and non-sustainable patterns. The proper analysis of the design and research issue has to be made on the product and the approval to be provided with the proper clarification. The enhancement of the sustainable concept and analysis of flow activity in the straightforward will improve the product in the market sector. The positive approach of the product results in profit in the production sector of the Electronic Manufacturing Industry. Thus, the organizational profit is increased overall which results in a positive trend due to the technological contribution. Environmental sustainability is considered for the constant growth of the green product in this competitive world. The impact of the green process mainly depends on the quantity of the natural resources exploited. Population, affluence, and technological impact per unit resources are the division of impacts.

Impact on Environment $=\mathrm{g}$ (population, affluence, technology).

The positive impact on the environment is attained in a qualitative term such as the intensity of materials, energy accounting, and life cycle evaluation. Thus, the research helps us in detecting the risk issue of developing a green product in Electronic Manufacturing Industries.

\section{CONCLUSION:}

Green product design and manufacturing is widespread in today's business environment. Knowing the advantage of green technology many Electronic Manufacturing Industries are eagerly involved in implementation of Green Supply Chain Management (GSCM). GSCM provides a sustainable supply chain with the benefits such as low cost, risk management, produce new sources and boost the product value. The Green Logistics Management (GLM) plays an important role in globalization production as it minimizes the effect arising from manufacturing and production activities on environment. The green process encourages developing a recycling product that includes eco-design with a significant life span. Electronic Manufacturing companies such as Microprocessor company, computers, PCB, and circuit boards are highly benefited by using this technology. The graphical representation shows that both the environmental and operational performance are obtained through the Green Supply Chain Management. Thus, the Electronic Manufacturing Industries are switching on to develop green product to boost their brand in market. 


\section{Declaration}

Funding

Not Applicable

\section{Conflicts of interest/Competing interests.}

The authors declare that they have no conflict of interest.

\section{Availability of data and material}

Not Applicable

\section{Code availability}

Not Applicable

\section{REFERENCE:}

[1] Latifah Abd Manaf, MohdArmi Abu Samah and Nur IlyanaMohdZukki(2008), "Municipal solid waste management in Malaysia: Practices and challenges", Department of Environmental Sciences, Faculty of Environmental Studies, Universiti Putra Malaysia, 43400 UPM Serdang, Selangor, Malaysia.

[2] K. H. Lai; C. W. Y. Wong, "Green logistics management and performance: Some empirical evidence from Chinese manufacturing exporters”, Omega 2012, 40, 267-282.

[3] X. Heng; C. Zou, "How can Green Technology Be Possible”, Asian Soc. Sci. 2010, 6.

[4] Y. S. Chen, "The Drivers of Green Brand Equity: Green Brand Image, Green Satisfaction, and Green Trust”, J. Bus. Ethics 2010, 93, 307-319.

[5] I. D. Paul; G. P. Bhole; J. R. Chaudhari, "A review on Green Manufacturability of a Unit Production Process Using Simulation”, Procedia CIRP 2015, 29, 257-262.

[6] A. McWilliams; A. Parhankangas; J. Coupet; E. Welch; D. T. Barnum, "Strategic Decision Making for the Triple Bottom Line: Strategic Decision Making”, Bus. Strategy Environ. 2016, 25,193-204.

[7] J. Sarkis; Q. Zhu, "Environmental sustainability and production: Taking the road less travelled", Int. J. Prod. Res. 2018, 56, 743-759.

[8] S. H. Bonilla; C. M. V. B. Almeida; B. F. Giannetti; D. Huisingh, "Key elements, stages and tools for a sustainable world: An introduction to this special volume", J. Clean. Prod. 2013, 46, 17.

[9] K. H. Robert; B. Schmidt-Bleek; J. Aloisi de Larderel; G. Basile; J. L. Jansen; R. Kuehr; P. Price Thomas; M. Suzuki; P. Hawken; M. Wackernagel, "Strategic sustainable development- 
selection, design and synergies of applied tools", Journal of Cleaner Production 10, 197214(2002).

[10] S. Byggeth; E. Hochschorner, "Handling trade-offs in Ecodesign tools for sustainable product development and procurement", Journal of Cleaner Production 14, 1420-1430 (2006).

[11] N. Van Nes; J. Cramer, "Product lifetime optimization: a challenging strategy towards more sustainable consumption patterns", Journal of Cleaner Production 14, 1307-1318 (2006).

[12] H. Baumann; F. Boons; A. Bragd, "Mapping the green product development field: engineering, policy and business perspectives", Journal of Cleaner Production 10, 409-425 (2002).

[13] T. Short; A. Lee-Mortimer; C. Luttropp; G. Johansson, "Manufacturing, sustainability, ecodesign and risk: lessons learned from a study of Swedish and English companies", Journal of Cleaner Production 37, 342-352 (2012).

[14] N. Bey; M. Z. Hauschild; T. C. McAloone, "Drivers and barriers for implementations of environmental strategies in manufacturing companies", CIRP Annals-Manufacturing Technology 62, 43-46 (2013).

[15] C. Boks, "The soft side of eco-design", Journal of Cleaner Production 14, 1346-1356 (2006).

[16] D. C. A. Pigosso; H. Rozenfield; T. C. McAloone, "Ecodesign maturity model: a management framework to support eco-design implementation into manufacturing companies", Journal of Cleaner Production 59, 160-173 (2013).

[17] F. Brones; M. M. de Carvalho; E. de SenziZancul, "Ecodesign in project management: a missing link for the integration of sustainability in product development?", Journal of Cleaner Production 80, 106-118 (2014).

[18] M. Lindahl, "Engineering designers experience of design for environmental methods and tools- Requirement definitions from an interview study", Journal of Cleaner Production 14, 487496 (2006).

[19] S. Thiede; G. Posselt; C. Herrmann, "SME appropriate concept for continuously improving the efficiency and resource efficiency in manufacturing companies", CIRP Journal of Manufacturing Science and Technology, 2013; 6: 3: 204-211.

[20] GhadimiPouya, Li Wen, Kara Sami, Herrmanna Christoph, "Integrated Material and Energy Flow Analysis towards Energy Efficient Manufacturing", $21^{\text {st }}$ CIRP Conference on Life Cycle Engineering, Procedia CIRP, 2014; 15: 117-122.

[21] R. Church; W. Hecox; S. Dreseners; A. Edwards, "Sustainable development: oxymoron? Or opposed by morons?”, Sustainable Development - EV141. Colorado College, 2008, p. 3.

[22] S. Dresener, "Principles of Sustainability", London: Earthscan Publications Ltd., 2008, p. 30.

[23] G. H. Brundtland, "Report of the World Commission on Environment and Development: Our Common Future", World Commission on Environment and Development, New York: United Nations, 1987, p. 24. 
[24] D. Bartlett; A. Trifilova, "Green technology and eco-innovation: seven case-studies from a Russian manufacturing context", Journal of Manufacturing Technology Management, 21, 8, 910929,2010, p. 2.

[25] R. Kemp; P. Pearson, "Final report of the MEI project measuring eco innovation", UM Merit Maastricht, Available at http://www.merit.unu.edu/MEI/deliverables/MEI\%20D15\%20Final\%20report\%20about\%20mea suring\%20eco-innovation.pdf.

[26] A. Reid; M. Miedzinski, "Eco-innovation final report for Sectoral Innovation Watch", final report to Europe INNOVA initiative, Technopolis Group, 2008, p. 7, Available at http://www.technopolis-group.com/cms.cgi/site/downloads/index.htm.

[27] M. M. Andersen, "Eco-innovation towards a taxonomy and a theory", $25^{\text {th }}$ Celebration DRUID Conference 2008 on Entrepreneurship and Innovation-Organizations, Institutions, Systems and Regions, Copenhagen, Denmark, 2008, p. 5.

[28] A. Arundel; R. Kemp, "Measuring eco-innovation", United Nations University - Maastricht Economic and Social Research and Training Centre on Innovation and Technology, Maastricht, UNU-MERIT\#2009-017, 2009, p. 34.

[29] V. Oltra; M. Saint Jean, "Sectoral systems of environmental innovation: an application to the French automotive industry", Technological Forecasting and Social Change, 76, 567-583, 2009, p. 567.

[30] Y. S. Chen; S. B. Lai; C. T. Wen, "The influence of green innovation performance on corporate advantage in Taiwan", Journal of Business Ethics, 67, 4, 331-339, 2006, p. 534.

[31] S. S. Kamble; A. Gunasekaran; S. A. Gawankar, "Sustainable Industry 4.0 framework: A systematic literature review identifying the current trends and future perspective", Process Saf. Environ. Prot. 2018, 117, 408-425.

[32] M. Ghobakhloo, "Industry 4.0, digitalization, and opportunities for sustainability", J. Clean. Prod. 2020, 252, 119869.

[33] D. Couckuyt; A. Van Looy, "Green BPM as a Business-Oriented Discipline: A systematic Mapping Study and Research Agenda", Sustainability 2019, 11, 4200.

[34] D. Couckuyt; A. Van Looy, "A systematic review of Green Business Process Management", Bus. Process Manag. J. 2019, 26, 421-446.

[35] S. M. Abdelbasir; C. T. El-Sheltawy; D. M. Abdo, "Green Processes for Electronic Waste Recycling: A review”, J. Sustain. Metall. 2018, 4, 295-311.

[36] F. Chemat; N. Rombaut; A. Meullemiestre; M. Turk; S. Perino; A. S. Fabiano-Tixier; M. Abert-Vian, "A review of Green Food Processing techniques, Preservation, transformation and extraction”, Innov. Food Sci. Emerg. Techol. 2017, 41, 357-377. 
[37] E. Ramsey; Q. B. Sun; Z. Q. Zhang; C. M. Zhang; W. Gou, "Mini-Review: Green sustainable processes using supercritical fluid carbon dioxide

[38] N. K. Singh; P. M. Pandey; K. K. Singh; M. K. Sharma, "Steps towards green manufacturing through EDM process: A review", Cogent Eng. 2016, 3.

[39] N. Kumar; R. P. Agrahari; D. Roy, "Review of Green Supply Chain Processes", Ifac Pap. 2015, 48, 374-381.

[40] J. S. Gephart; H. D. Peterson; S. M. Bratkovich, "Green Dimensioning - A review of processing, handling, drying and marketing”, For. Prod. J. 1995, 45, 69-73.

[41] D. Kralisch; D. Otto; D. Gericke, "Rules and benefits of Life Cycle Assessment in green chemical process and synthesis design: A tutorial review", Green Chem. 2015, 17, 123-145.

[42] M. V. Kolb, "Green Organic Chemistry and Its Interdisciplinary Applications", Taylor Francis: Boca Raton, FL, USA, 2017.

[43] R. J. Mendoza-Fong; L. J. Garcia-Alcaraz; R. J. Diaz-Reza; E. Jimenez-Macias; J. BlancoFernandez, "The role of Green Attributes in Production Processes as Well as Their Impact on Operational, Commercial, and Economic Benefits", Sustainability 2019, 11, 1294.

[44] Q. Shi; X. D. Lai, "Identifying the underpin of green and low carbon technology innovation research: A literature review from 1994 to 2010", Technol. Forecast. Soc. Chang. 2013, 80, 839864.

[45] T. Schiederig; F. Tietze; C. Herstatt, "Green innovation in technology and innovation management-an exploratory literature review", R D Manag. 2012, 42, 180-192.

[46] N. Adnan; S. M. Nordin; M. A. Bahruddin; A. H. Tareq, "A state-of-the-art review on facilitating sustainable agriculture through green fertilizer technology adoption: Assessing farmer's behavior", Trends Food Sci. Technol. 2019, 86, 439-452.

[47] H. H. Tong; Z. Y. Yao; J. W. Lim; L. W. Mao; J. X. Zhang; T. S. Ge; Y. H. Peng; C. H. Wang; Y. W. Tong, "Harvest green energy through energy recovery from waste: A technology review and an assessment of Singapore", Renew. Sust. Energ. Rev. 2018, 98, 163-178.

[48] N. Ramali; N. Mazlan; Y. Ando; Z. Leman; K. Abdan; A. A. Aziz; N. A. Sairy, "Natural fiber for green technology in automotive industry: A brief review", In Wood and Biofiber International Conference; M. Jawaid; N. Mazlan; IOP Conference Series-Materials Science and Engineering; Iop Publishing Ltd.: Bristol, UK, 2018; Volume 368, ISBN 1757-8981.

[49] R. E. Gumba; S. Saallah; M. Misson; C. M. Ongkundon; A. Anton, "Green biodiesel production: A review on feedstock, catalyst, monolithic reactor, and supercritical fluid technology", Biofuel Res. J. 2016, 3, 431-447.

[50] W. Abdelmoez; E. Ashour; S. M. Naguib, "A Review on Green Trend Oil Extraction Using Subcritical Water Technology and Biodiesel Production”, J. Oleo Sci. 2015, 64, 467-478. 
[51] M. A. Quader; S. Ahmed; R. A. R. Ghazilla; M. Dahari, "A comprehensive review on energy efficient $\mathrm{CO}_{2}$ breakthrough technologies for sustainable green iron and steel manufacturing", Renew. Sust. Energ. Rev. 2015, 50, 594-614.

[52] D. G. Ahn, "Direct Metal Additive Manufacturing Processes and Their Sustainable Applications for Green Technology: A Review", Int. J. Precis EngManuf-Green Technol. 2016, 3, 381-395.

[53] R. Kumar; S. P. Singh; K. Lamba, "Sustainable robust layout using Big Data approach: A key towards industry 4.0", J. Clean Prod. 2018, 204, 643-659. 
Figures

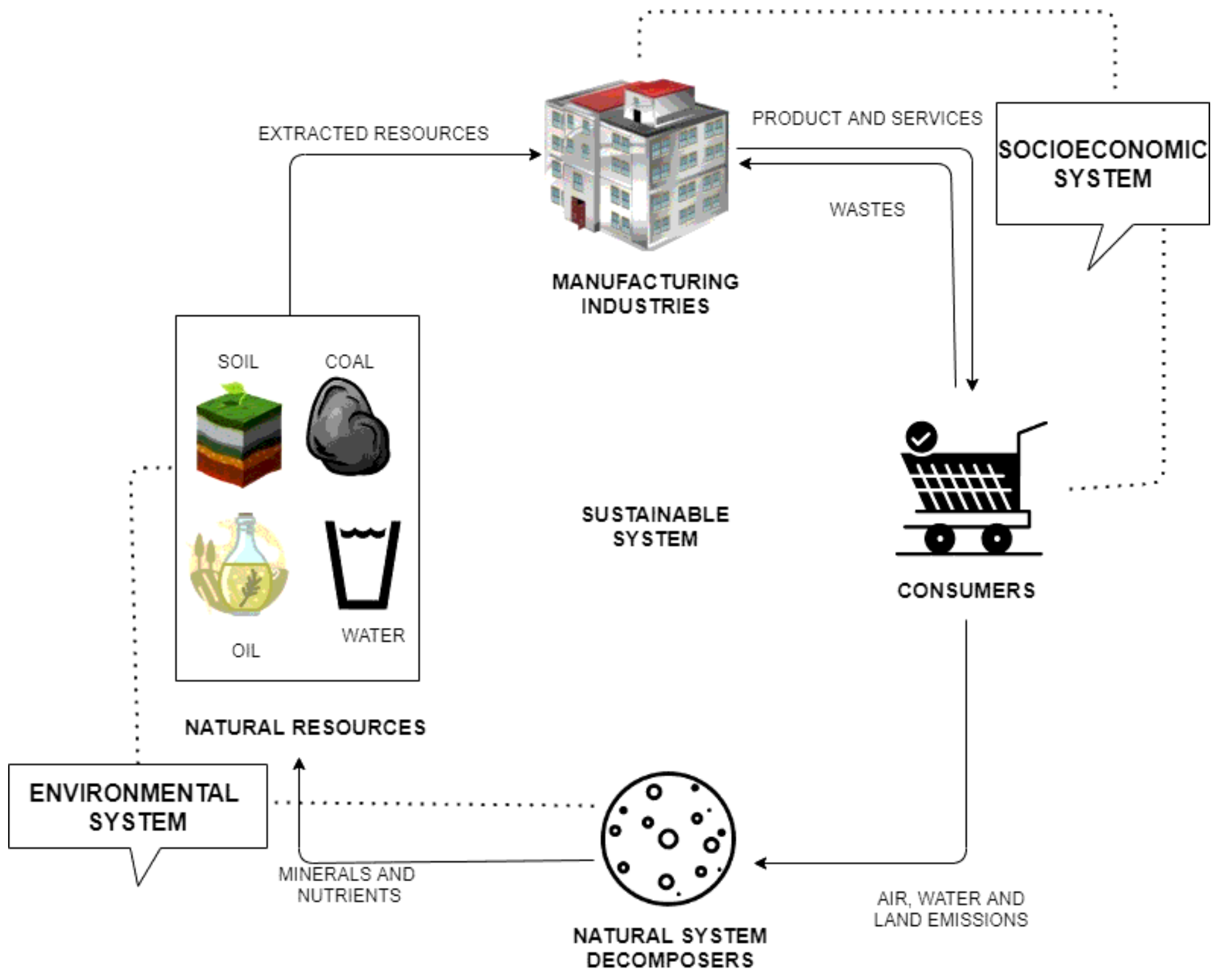

Figure 1

Green Product Manufacturing for a Sustainable Development. 


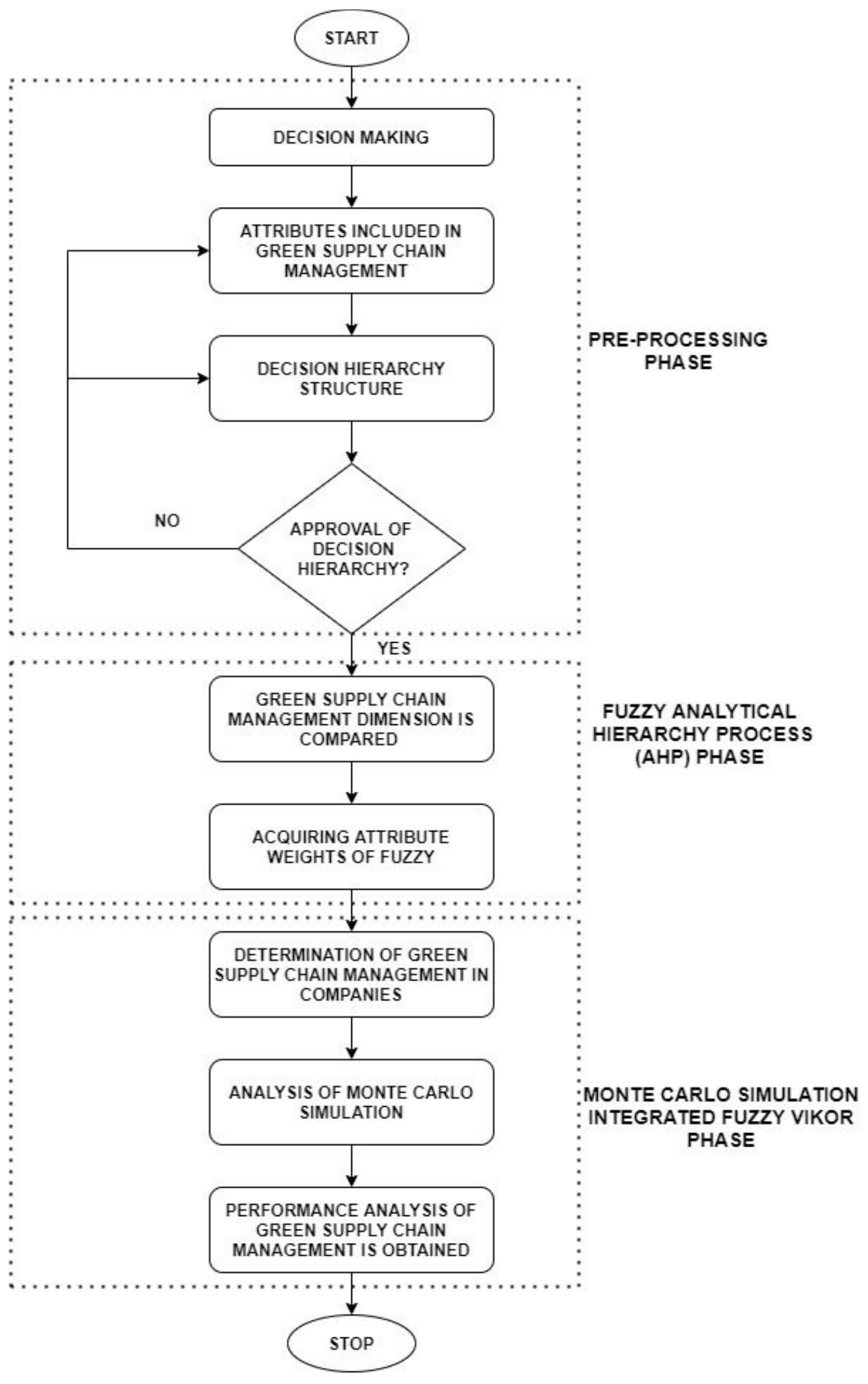

Figure 2

Green Supply Chain Management. 


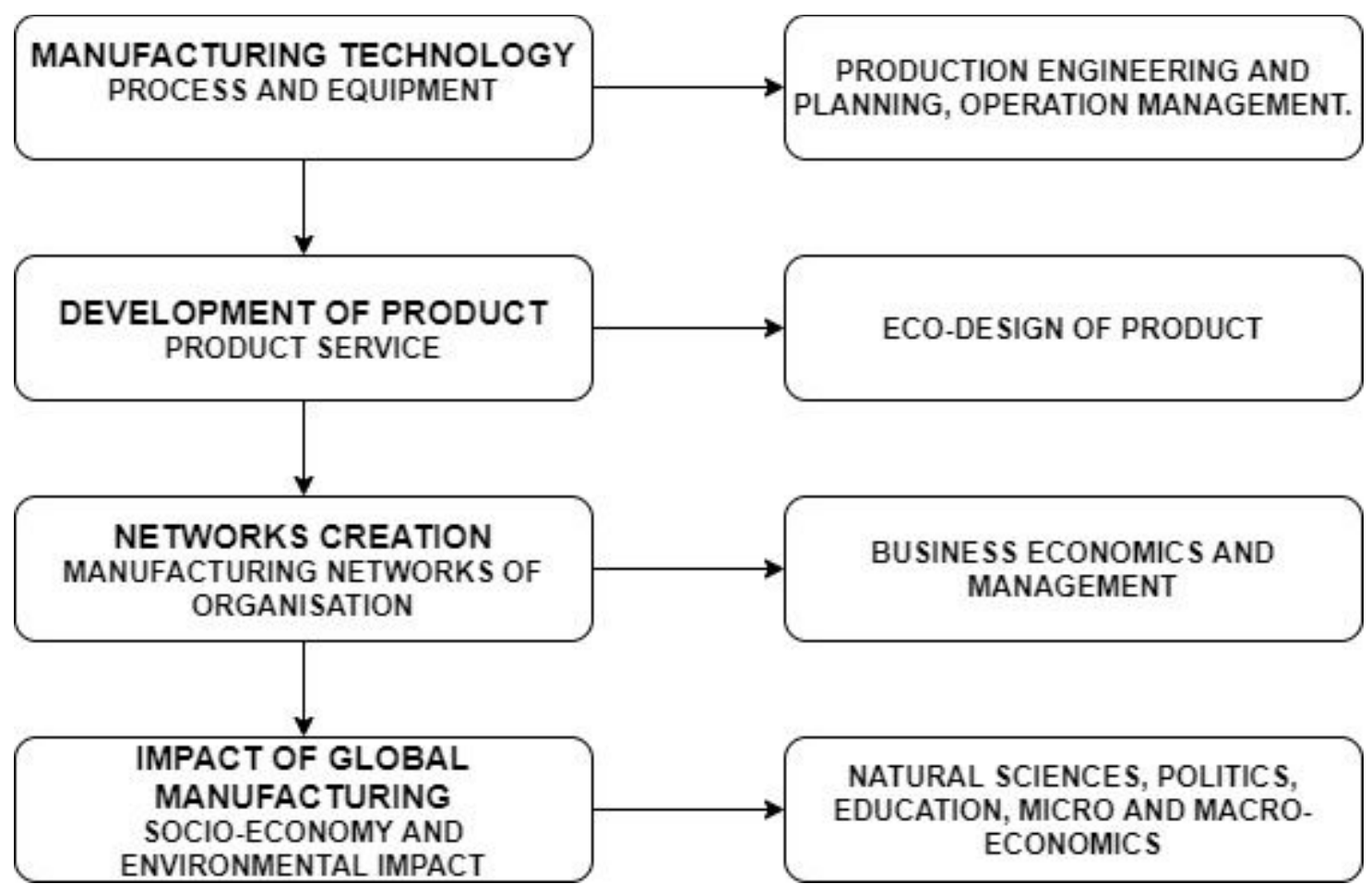

Figure 3

Flowchart for Sustainable Manufacturing.

\section{Green Logistic Management}

4.5

4

3.5

3

2.5

2

1.5

1

0.5

0

High Environmental Regulatory Pressure at Low Customer Pressure in

Manufacturing Industries

Green Logistic Management

Figure 4 
Green Logistic Management at Low Customer Pressure.

\section{Green Logistic Management}

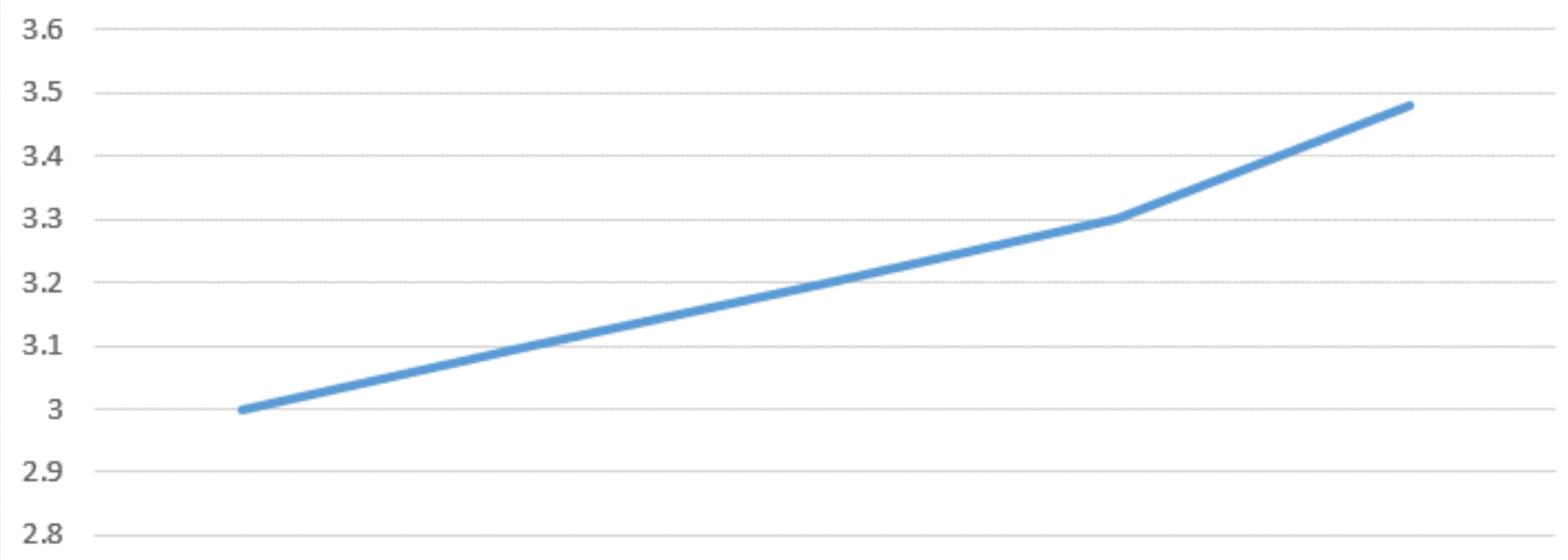

2.7

Low Environmental Regulatory Pressure at High Customer Pressure in Manufacturing Industries

Green Logistic Management

\section{Figure 5}

Green Logistic Management at High Customer Pressure. 


\section{Environmental performance}

5.2

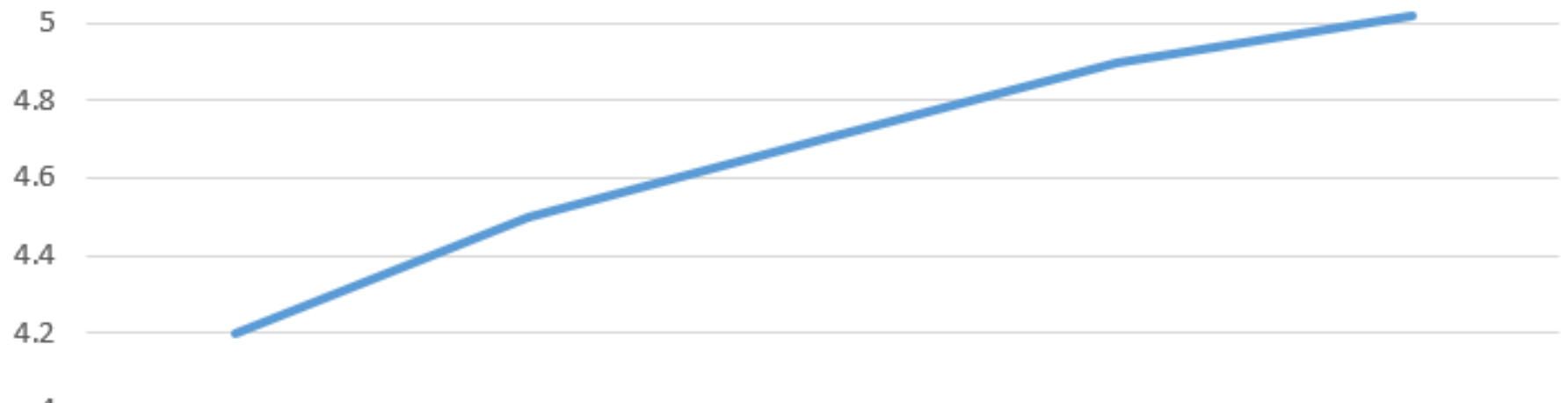

4

3.8

3.6

High Environmental Regulatory Pressure with low Green Logistic Management.

Green Logistic Management

\section{Figure 6}

Environmental performance of Green Logistic Management.

\section{Environmental performance}

3.95

3.9

3.85

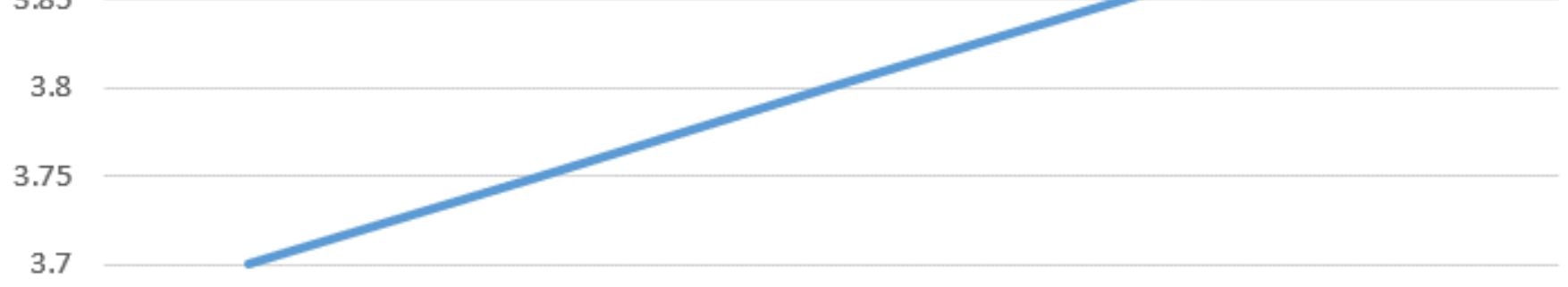

3.65

3.6

Low Environmental Regulatory Pressure with high Green Logistic Management. 
Figure 7

Environmental performance of Green Logistic Management.

\section{Green Logistics Management}

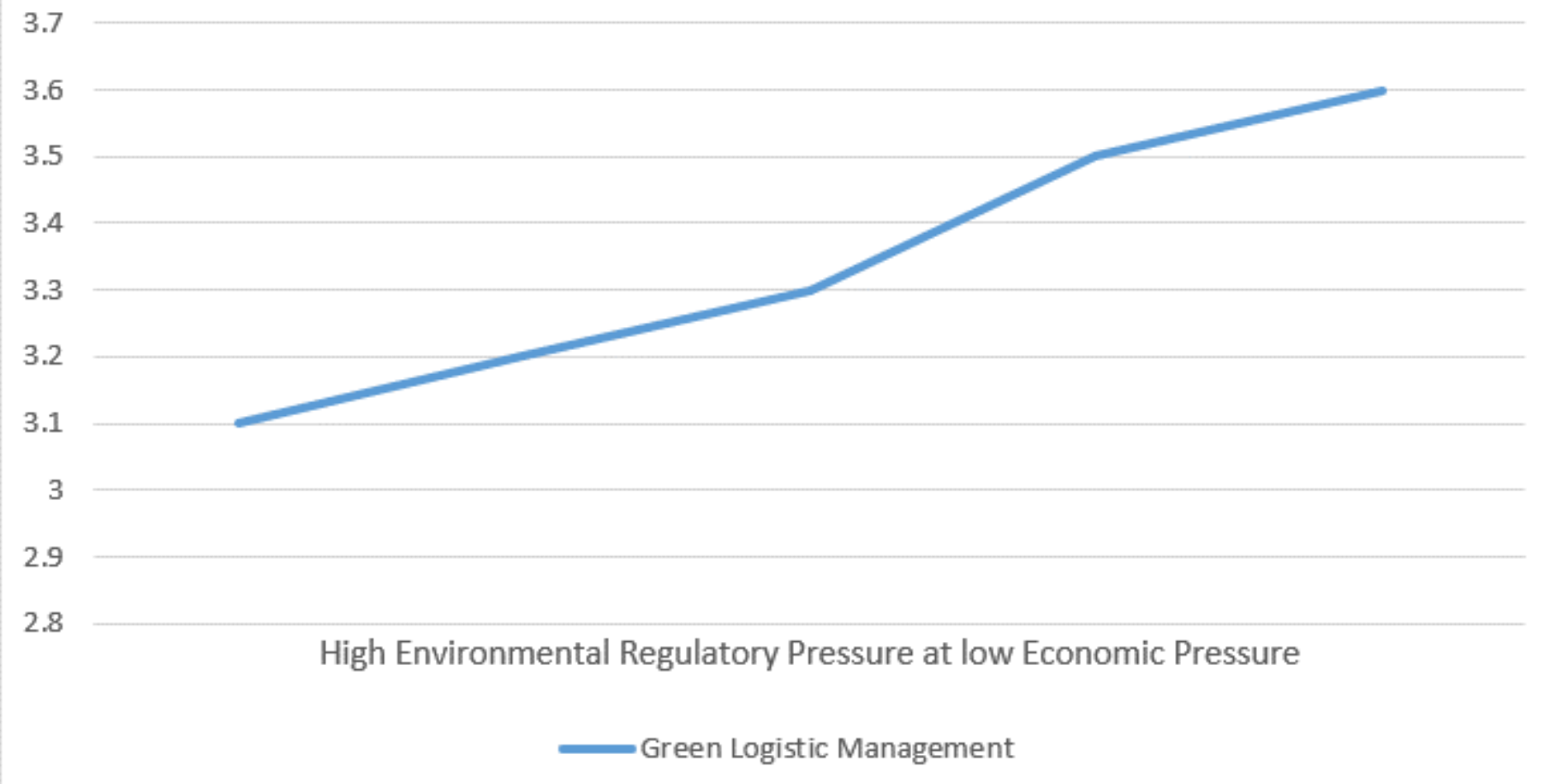

\section{Figure 8}

Green Logistic Management at Low Economic Pressure. 


\section{Green Logistics Management}

3.15

3.1

3.05

3

2.95

2.9

2.85

2.8

Low Environmental Regulatory Pressure at High Economic Pressure

Green Logistic Management

\section{Figure 9}

Green Logistic Management at High Economic Pressure.

\section{Operational Performance}

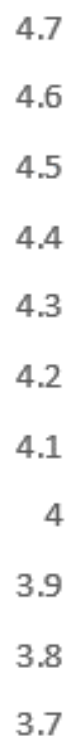

3.7

High Environmental Regulatory Pressure with low Green Logistic Management 
Figure 10

Operational performance of Green logistic management.

\section{Operational Performance}

4.1

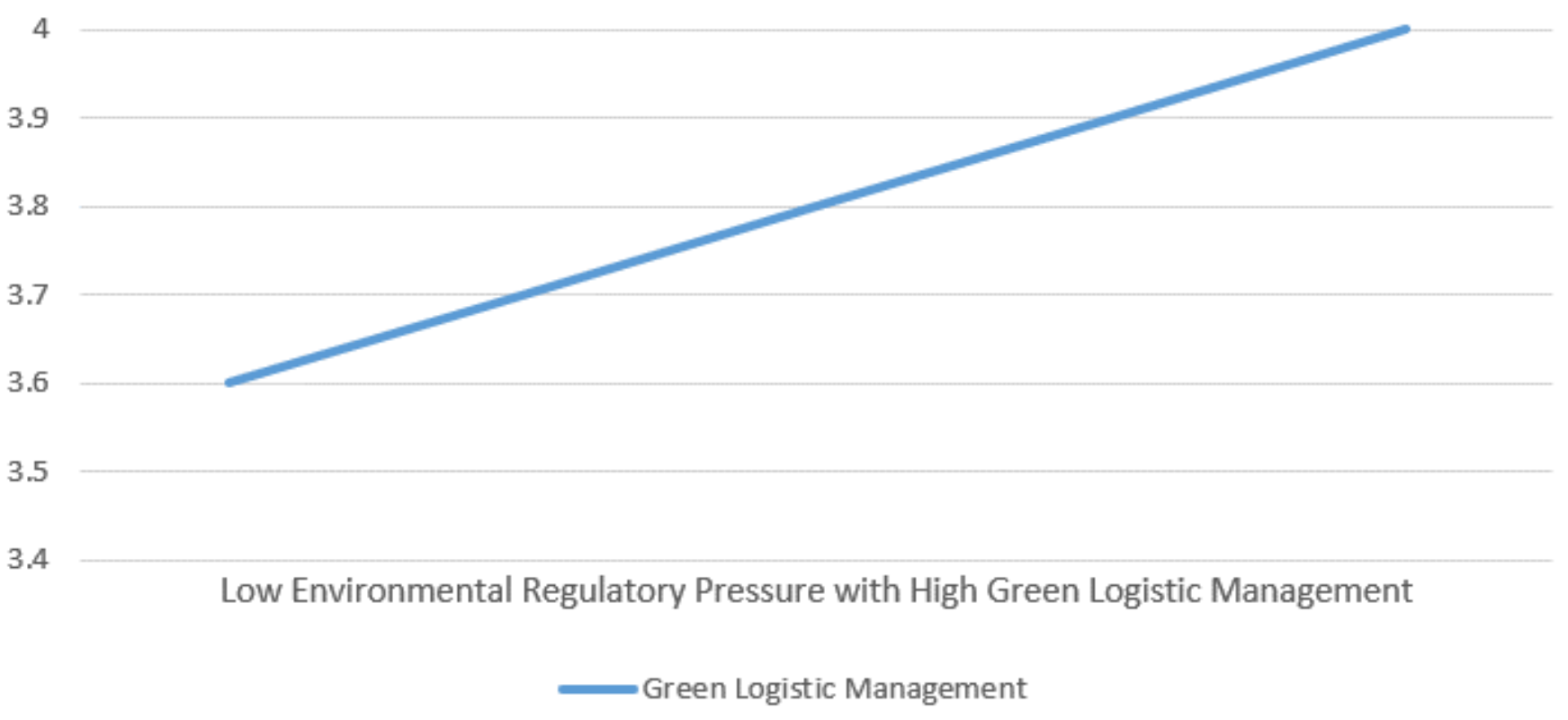

\section{Figure 11}

Operational performance of Green logistic management. 